\title{
Growing Risks
}

Summary: The risks to the global economy are growing and so are risks to Russia's growth. Russia's short-term economic and fiscal situation remains favorable because of high oil prices with an almost balanced budget this year. But the balance of macroeconomic risks has shifted toward an uncertain growth path as inflation pressures subside and external risks rise sharply. The large non-oil fiscal deficit requires concerted medium-term fiscal adjustment to reduce vulnerability in the face of new shocks, to replenish fiscal buffers, and to move toward a longerterm sustainable level of non-oil deficits.

With heightened external risks because of the slowdown in the United States and the European Union, the sovereign debt crisis in Europe and attendant decline in oil prices, we now expect Russia's real GDP to grow 4 percent in 2011 (down from 4.4 percent expected in June). Although the aggregate, short-term unemployment picture is favorable, unemployment remains very high in many regions, especially in the North Caucasus district, reflecting investment climate, and structural factors. After five years of little improvement in poverty, with more moderate growth than before the crisis, further gains in poverty will be more difficult, requiring a concerted effort at improving the effectiveness of public expenditures and the targeting of social programs.

\section{Russia's Recent Economic Developments}

\section{Russia's Economic and Social Outlook, 2011-12}

\section{In Focus: The World Oil Market: Developments and Prospects}

WORLD BANK

\section{http://www.worldbank.org/eca/rer http://www.worldbank.org.russia}

\footnotetext{
* The report was prepared by a World Bank core team consisting of Sergei Ulatov (Economist), Olga Emelyanova (Research Analyst), and Victor Sulla (Economist), under the direction of Zeljko Bogetic (Lead Economist and Country Sector Coordinator for economic policy for Russia and the general editor of the report). Mikhail Matytsin (consultant-intern) authored the box on consumption and David Tarr contributed the box on WTO. Lucio Vinhas da Souza (Senior Economist) and Shane Streifel (Consultant) contributed on the international environment and the global oil market. The team expresses gratitude to the World Bank Global Economic Prospects team led by Andrew Burns (Manager, Development Prospects Group) for close collaboration and discussions on global economic environment and its links with the Russian Federation. Advice from and discussions with Pedro Alba (Country Director for Russia); Yvonne Tsikata (Director for Poverty Reduction and Economic Management in the Europe and Central Asia Region); and Benu Bidani (Sector Manager for Russia, Ukraine, Belarus, and Moldova) are gratefully acknowledged.
} 


\section{RUSSIAN ECONOMIC REPORT No. 26}

\section{RECENT ECONOMIC DEVELOPMENTS}

Summary. Russia's economic growth slowed in the second quarter of 2011 as the inventory restocking cycle waned. High oil prices have kept the external current account in surplus but capital outflows continue. Gradually improving labor market conditions and access to credit and external borrowing are supporting domestic consumption but consumer confidence and external risks are constraining a more robust growth in domestic demand. Inflation is on a downward trend because of seasonal factors. The short-term fiscal situation is favorable mainly because of high oil prices with an almost balanced budget this year. But a large non-oil deficit requires concerted medium-term fiscal adjustment to replenish fiscal buffers and to move toward long-term sustainable levels of the non-oil deficit.

\section{GLOBAL TRENDS — growing risks, declining commodity prices}

Downside risks to global growth-especially in high-income countries-and commodity prices have risen sharply since August. The dramatic mark-down to U.S. sovereign debt ratings, and the lower-thanexpected growth in the U.S. and European Union (EU) in the first half of 2011, coupled with new global market turbulence and renewed uncertainties about the European debt crisis, have resulted in downward revisions to the global outlook. High-income countries' real gross domestic product (GDP) growth of 2.7 percent in 2010 is now expected to slow to 1.6 percent in 2011, reflecting weak domestic demand with continuing troubles in the financial sector (figures 1.1 and 1.2). As a result, monetary authorities in the United States and the Eurozone have signaled their concern about the pace of economic growth and their willingness to provide a supportive monetary and financial environment for an extended period. The G-7 finance ministers and central bank governors at the September meeting in Marseilles noted a clear slowdown in global growth as well as their commitment to a strong and coordinated international response to these new challenges.

The likely slowdown in growth in low- and middle-income countries is less pronounced, from more than 7 percent in 2010 to around 6 percent in 2011, but it does emphasize the dependence of global growth on developing countries, especially China. With rising risks and uncertainty and recent stock market turbulence (figure 1.3), capital flows to developing countries fell to a 10-month low and bank flows to only US\$8 billion in July, the second-lowest monthly level since January-March 2009 (figure 1.4). Commodity prices, which peaked in February 2011, accelerated their decline during the summer months because of expectations of weaker demand. 
Figure 1.1: Global Industrial Production: Output Momentum Slowing

industrial production, seasonally adjusted annualized rate (\%)

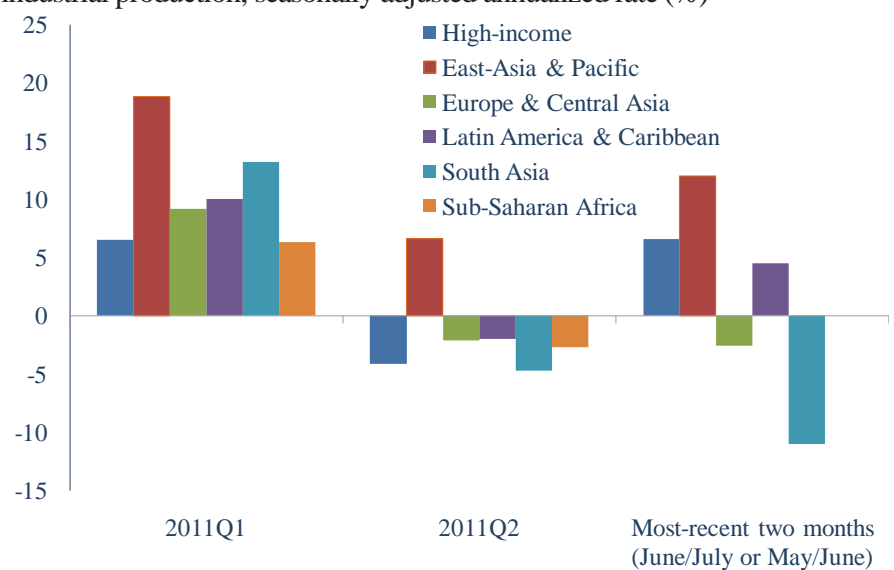

Source: World Bank staff. Region-wide second quarter data are not available for MNA.
Figure 1.2: Global Trade Growth Loses Some Speed, as Output Momentum Slows

contribution to growth of global import volumes, $3 \mathrm{~m} / 3 \mathrm{~m}$ saar

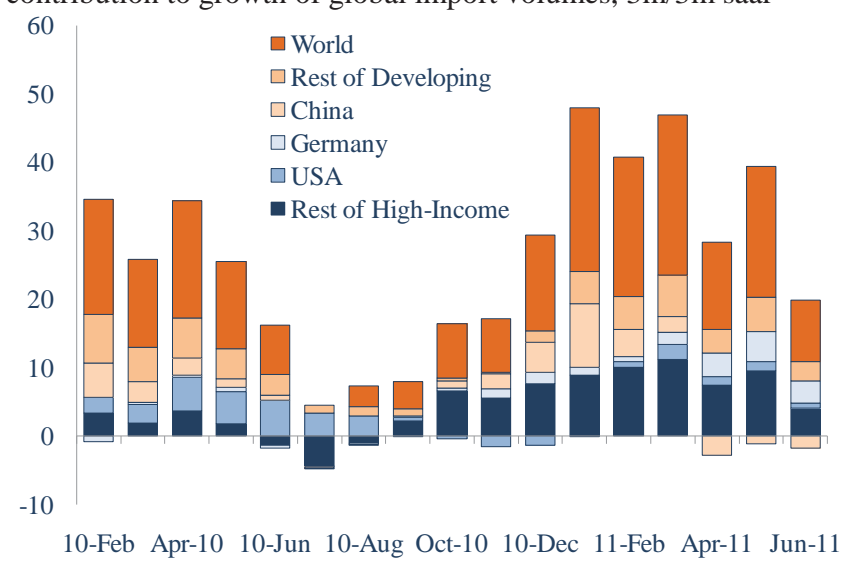

Source: World Bank staff.
Figure 1.3: Selected Credit Default Swap Spreads

five-year sovereign credit default swaps, basis points

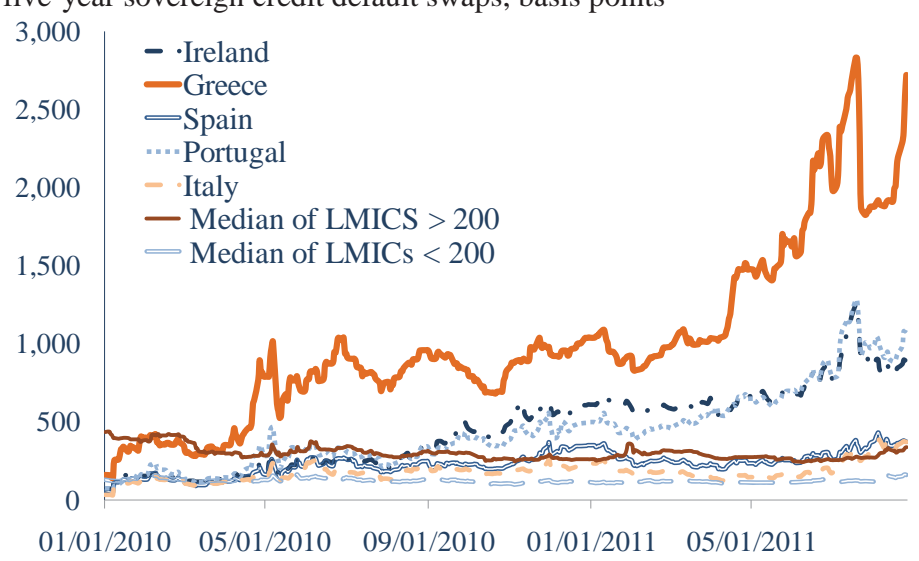

Source: Datastream, World Bank staff calculations.
Figure 1.4: Capital Flows to Developing Countries US\$ billions

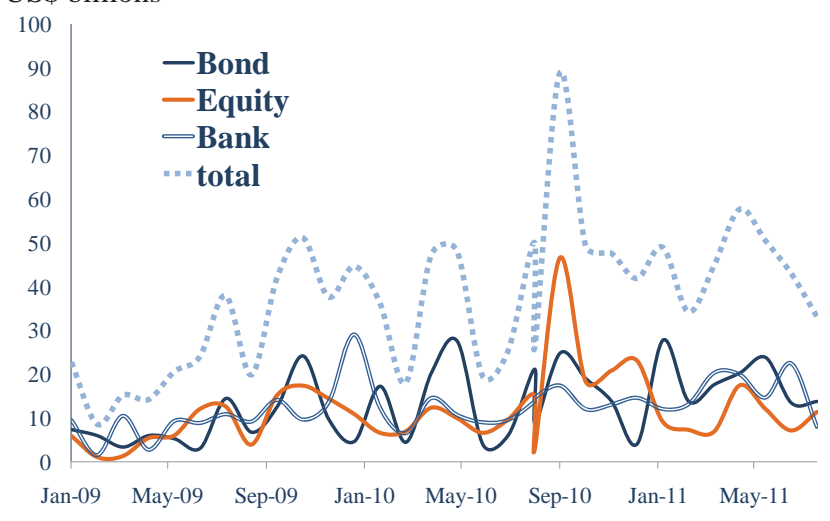

\section{RUSSIAN FEDERATION'S OUTPUT GROWTH — slower than expected amid growing risks}

Preliminary real GDP statistics suggest that Russia's economic growth slowed in the second quarter of 2011 as the inventory restocking cycle waned. According to the first Rosstat estimate, Russia's economy grew by 3.4 percent in the second quarter (Q2) of 2011 year-on-year (y-o-y) compared to 4.1 percent in Q1 2010 (table 1.1). The estimated growth for the first half of 2011 was 3.7 percent, down from 4.3 percent a year earlier, surprising most analysts. Although partly reflecting the base effect from the strong GDP rebound in Q2 2010, growth in domestic demand has not been as strong as anticipated. With the inventory restocking cycle coming to an end, fixed capital investments grew at a sluggish rate of 2.7 percent in the first half (H1) of $2011 \mathrm{y}-0-\mathrm{y}$, while private consumption growth appears to have been constrained by continued, low consumer confidence likely associated with a delayed recovery in real incomes. Nevertheless, consumption growth is likely to lead short-term growth even in the environment of more moderate growth and oil prices (box 1.1). 
Table 1.1: GDP Growth by Main Sectors (Value Added), 2007-11

\begin{tabular}{lcccccc}
\hline & 2007 & 2008 & 2009 & 2010 & $\mathrm{Q} 1-2011$ & Q2-2011 \\
\hline GDP growth & $\mathbf{8 . 5}$ & $\mathbf{5 . 2}$ & $\mathbf{- 7 . 8}$ & $\mathbf{4 . 0}$ & $\mathbf{4 . 1}$ & $\mathbf{3 . 4}$ \\
Tradable sector & $\mathbf{3 . 6}$ & $-\mathbf{0 . 2}$ & $-\mathbf{8 . 0}$ & $\mathbf{6 . 3}$ & $\mathbf{8 . 3}$ & $\mathbf{4 . 7}$ \\
$\quad$ Agriculture, forestry & 1.3 & 6.4 & 1.3 & -10.7 & 1.1 & 0.5 \\
$\quad$ Extraction industries & -2.2 & 1.0 & 0.5 & 4.7 & 2.4 & 2.2 \\
$\quad$ Manufacturing & 7.5 & -2.1 & -14.9 & 12.3 & 12.9 & 6.9 \\
Nontradable sector & $\mathbf{1 2 . 4}$ & $\mathbf{9 . 2}$ & $-\mathbf{- 7 . 2}$ & $\mathbf{2 . 9}$ & $\mathbf{2 . 4}$ & $\mathbf{2 . 4}$ \\
$\quad$ Electricity, gas, and water & -3.4 & 0.7 & -5.0 & 5.5 & -0.3 & 2.0 \\
production and distribution & 13.0 & 11.1 & -14.6 & -0.7 & 0.8 & 0.1 \\
$\quad$ Construction & 11.7 & 9.9 & -6.2 & 5.0 & 1.3 & 2.3 \\
$\quad$ Wholesale and retail trade & 4.8 & 5.2 & -8.5 & 7.7 & 5.1 & 3.7 \\
$\quad$ Transport and communication & 29.1 & 13.5 & 2.2 & -2.4 & 2.0 & 2.5 \\
$\quad$ Financial services & & & & &
\end{tabular}

Sources: Rosstat; World Bank staff estimates.

\section{Box 1.1: What Drives Consumption in Russia?}

Understanding the factors driving consumption-the largest macroeconomic aggregate-is important for understanding short-term movements in economic activity and for developing a more precise view of the immediate economic outlook. To this end, using time-series analysis, including the cointegration framework and a vector errorcorrection model, we have investigated factors that may drive the household consumption in Russia. Preliminary results suggest three important factors that have a stable, long-term relationship with consumers' expenditures in Russia: (a) level of economic activity; (b) labor market conditions; and (c) the external environment (proxied by the price of oil). Box table 1 summarizes the long-term partial elasticities of consumption with respect to these factors. The estimation also shows a relationship, albeit much weaker, between consumption and other GDP components. There is a slight positive effect of investment and import and export shocks on consumption. The effect of economic policies appears to be weak and relatively insignificant (for example, the effect of government consumption).

Box table 1: Long-run Partial Elasticities for Consumptions ${ }^{\text {a }}$ percent

\begin{tabular}{lc} 
Real GDP & 0.8 \\
Unemployment rate & -2.0 \\
Oil price & 0.07 \\
\hline a. The percentage change in consumption with respect to a 1 percent change in real GDP or oil prices \\
or a 1 percentage point change in unemployment rate.
\end{tabular}

One result that stands out is the relationship between the labor market and consumption. The estimates (box table 1) show that the level of unemployment has a strong negative impact on consumption whereas short-term fluctuations in incomes do not translate into significant changes in consumption (for income, several different proxies were used to check the robustness-household disposable income, real wages, and pensions). One explanation could be the well-documented nature of the labor market adjustment in Russia, where an adjustment to negative shocks occurs mostly through wages, rather than employment. This makes incomes (especially labor income) a much more volatile variable. It appears that Russian consumers typically consider an income shock to be temporary, so they smooth their consumption on the basis of some average level of income, which could be interpreted as permanent income. At the same time, unemployment shocks are treated as more persistent, leading to an adjustment in consumption.

Source: World Bank staff estimates.

Recent data on sectoral gross output suggest a general slowdown across major sectors. Industrial production grew 5.3 percent in January-July 2011 y-o-y compared to 9.6 percent in January-July 2010, and 8.2 percent for 
2010. Manufacturing growth slowed the most - to 5.8 percent in Q2 2011 y-o-y, from 10.6 percent in Q1 2011 and 11.8 percent in 2010. Widespread expectations that growth in the nontradable sectors will soon accelerate, becoming the engines for economic growth, have not fully materialized. Growth rates in retail trade slowed to 5.3 percent in January-July 2011 y-o-y from 6.3 percent in 2010, while wholesale trade registered a decline of 0.2 percent in January-July 2011. The construction sector continued to disappoint in H1 2011 with a reported aggregate growth of only 1.2 percent and the housing construction declining by 3.7 percent during the same period. Growth in transport also slowed to 4.5 percent in January-July 2011 from 12.3 percent in the same period in 2010. While the aggregate statistics indicate a broad-based slowdown in economic activities during Q2 2011, the data for July 2011 reveal a growth momentum in selected nontradable sectors. For example, construction grew 17.6 percent in July 2011 y-o-y with housing construction expanding 19 percent. The turnover in wholesale trade rose 4.0 percent in July 2011 y-o-y after negative growth in the previous six months.

\section{BALANCE OF PAYMENTS — deteriorating because of capital outflows}

High oil prices have helped strengthen Russia's current account, but the overall balance of payments (BoP) position deteriorated in H1 2011 because of large net capital outflows (table 1.2). With average oil prices remaining well above US\$100 per barrel, the external current account balance slightly improved to US\$57.6 billion in H1 2011 from US\$52.1 billion despite a surge in imports, which grew by over 42 percent in January-June 2011 compared with the corresponding period in 2010 (figure 1.5). In contrast, the capital account considerably weakened during the first half of 2011 because of increased capital outflows. As a result, the overall BoP surplus has considerably narrowed in H1 2011, compared with H1 2010, albeit allowing the Central Bank of Russia (CBR) to accumulate about US\$23 billion in foreign currency reserves. (In contrast, in H1 2010, the CBR's reserves increased by US\$43 billion) (figure 1.6). Regarding trade policy, Russia made important progress toward World Trade Organization (WTO) membership; with remaining issues expected to be resolved, membership can now be anticipated in early 2012 (box 1.2). At the same time, on July 1, 2011, the Customs Union between Russia, Kazakhstan, and Belarus became operational, reflecting Russia's concerted efforts to increase trade, energy, and economic integration with countries in its vicinity.

Table 1.2: Balance of Payments, 2007-11

US\$ billions

\begin{tabular}{|c|c|c|c|c|c|c|}
\hline & 2007 & 2008 & 2009 & $2010^{a}$ & H1 2010 & H1 2011 \\
\hline Current account balance & 77.0 & 103.7 & 48.6 & 71.1 & 52.1 & 57.6 \\
\hline Trade balance & 130.9 & 155.4 & 111.6 & 151.4 & 86.1 & 101.7 \\
\hline Capital and financial account & 84.8 & -131.3 & -43.5 & -26.4 & -3.1 & -28.7 \\
\hline Errors and omissions & -12.9 & -11.3 & -1.7 & -8.0 & -6.3 & -6.0 \\
\hline Change in reserves (+ = increase) & 148.9 & -38.9 & 3.4 & 36.8 & 42.7 & 23.0 \\
\hline $\begin{array}{l}\text { Memo: average oil price (Brent, } \\
\text { US\$/barrel) }\end{array}$ & 72.5 & 96.9 & 61.5 & 79.5 & 77.3 & 111.0 \\
\hline
\end{tabular}

Source: CBR.

a. Preliminary estimates. 
Net capital outflows remained large in $\mathrm{H1} 2011$ despite high oil prices and continued moderate growth. According to the preliminary CBR estimates, net capital outflows from the private sector amounted to US\$31.2 billion in H1 2011, almost triple compared to H1 2010. This increase mostly reflects net outflows from the banking sector, which totaled US\$11.9 billion in H1 2011, compared to the net inflow of US\$7.6 billion in H1 2010 (table 1.3). Apparently, banks have been actively increasing their net foreign asset position through buying fixed income instruments and equities, mostly in the European markets as well as extending credits to external clients. By contrast, net outflows from the nonbanking corporate sector remained practically unchanged in H1 2011 at US\$19.3 billion (table 1.3). Interestingly, however, a closer look at quarterly flows shows that net capital outflows slowed somewhat in Q2 2011, likely reflecting two interrelated factors: (a) monetary tightening; and (b) a flexible exchange rate regime with limited interventions, which considerably curtailed opportunities for "carry trade." Also, there was a likely return to effective access to longer-term external credits by both Russian banks and nonfinancial corporations (see the following section on external debt).

Table 1.3: Net Capital Flows, 2006-11

US\$ billions

\begin{tabular}{cccccccccc}
\hline & $\mathbf{2 0 0 6}$ & $\mathbf{2 0 0 7}$ & $\mathbf{2 0 0 8}$ & $\mathbf{2 0 0 9}$ & $\mathbf{2 0 1 0}$ & H1 2010 & H1 2011 & Q1 2001 \\
\hline Total net capital inflows to the private sector & 41.4 & 81.7 & -133.9 & -56.9 & -35.3 & -11.5 & -31.2 & -21.3 \\
Net capital inflows to the banking sector & 27.5 & 45.8 & -56.9 & -31.4 & 15.9 & 7.6 & -11.9 & -7.7 & -19 \\
Net capital inflows to the nonbanking sector & 13.9 & 35.9 & -77 & -25.4 & -51.2 & -19.2 & -19.3 & -13.7 \\
\hline
\end{tabular}

Source: CBR.

Figure 1.5: Oil Prices and the Trade Balance

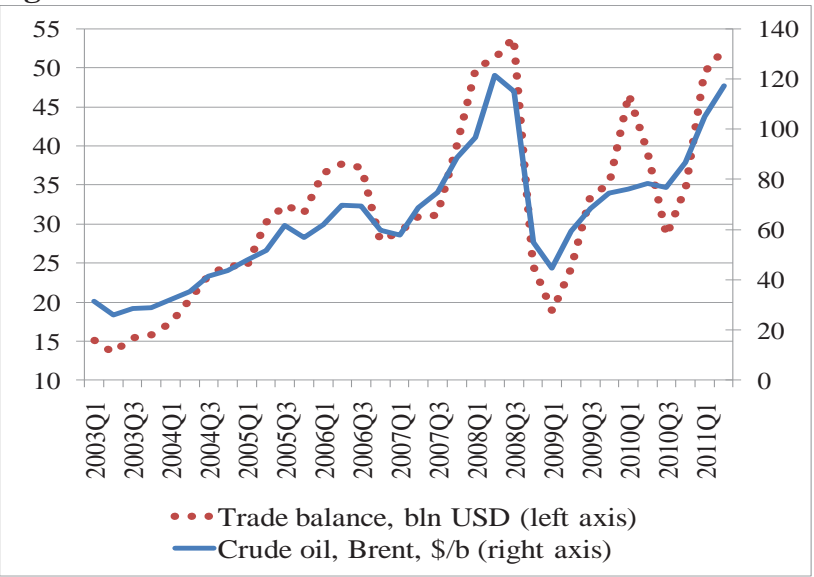

Sources: CBR; and World Bank staff estimates.
Figure 1.6: Current Account Balances (CABs) and the Real Effective Exchange Rate (REER)

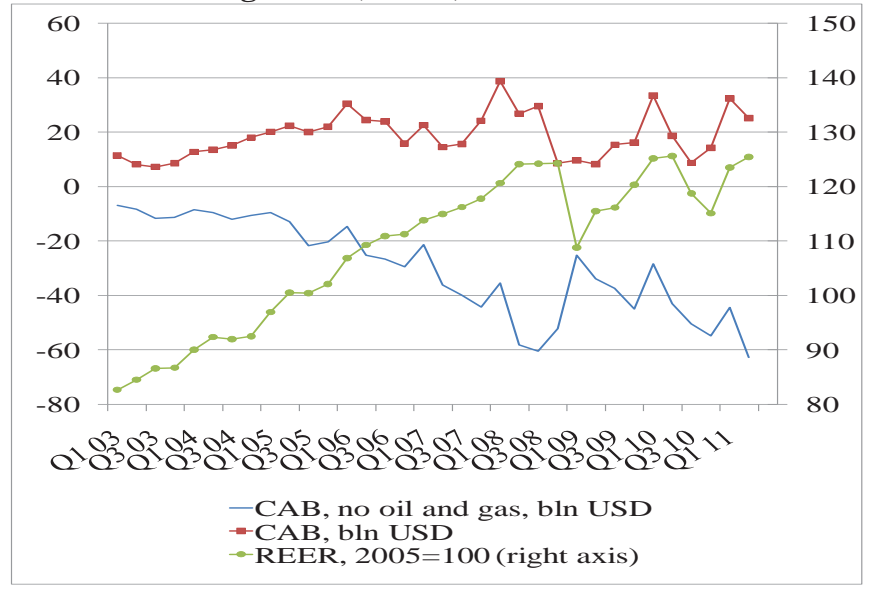

Source: World Bank staff calculations based on Rosstat and CBR data.

\section{EXTERNAL DEBT — improving access to longer-term financing}

Official debt statistics indicate that access to longer-term credits by Russian banks and corporations improved in the first half of 2011, before the rise in debt uncertainties in Europe. According to the CBR preliminary debt statistics, the outstanding external debt of the corporate sector increased to US\$485.6 billion (table 1.4) and that of the banking sector to US\$157.0 billion by end-June 2011 (an increase of 29 percent, y-0-y), while that of nonfinancial corporations rose to US\$328.5 billion (an increase of 14 percent, y-0-y). The latest 
statistics also show that access to long-term external financing has improved for private banks and corporations. The maturity structure of the private sector debt (table 1.5) shows that both banks and nonfinancial corporations increased their long-tem external liabilities in Q1 2011 (possibly reflecting future investment plans) while the share of short-term debt in total liabilities has been reduced.

\section{Box 2: Russia's Accession to the WTO: Progress, Issues, and Prospects}

Progress to date. Russia began its efforts to accede to the WTO in 1993 and is the largest country in the world that is not a member of the WTO. However, Russia has made great progress in its efforts to accede to the WTO. It has successfully signed bilateral market access agreements with all the approximately 60 members of the WTO Working Party (the largest Working Party on accession in WTO history). In September 2010, Russia's trade negotiators resolved all remaining bilateral trade issues with the United States and did the same with the European Union in December 2010. Russia now has the strong support of those two WTO powers for accession. Given the support of the two large powers at the WTO, momentum and hope for accession in 2011 have developed, and the Russian negotiators and their counterparts in their Working Party have been working very diligently this year to achieve accession in 2011.

Remaining issues. For accession to be achieved, remaining "systemic" issues must be resolved with the Working Party, namely, (a) clarification and agreement on Russia's sanitary and phytosanitary (SPS) conditions, (b) Trade Related Investment Measures (TRIMs) in automobiles, and (c) the permitted amount of trade-distorting agricultural subsidies. Further, Georgia would need to forego exercising its veto. As part of Russia's WTO accession negotiations, Georgia has raised the issue of transparent monitoring mechanisms of the customs posts among Russia and South Ossetia and Abkhazia. Importantly, negotiators for Russia and Georgia have met on multiple occasions in 2011 in an attempt to find a mutually acceptable framework. In response to the ecoli outbreak in Western Europe this year, members of the Working Party are pressing Russia on its SPS regulations, focusing on issues such as veterinary control, inspection systems, and system audits. For multinational automobile producers who operate in Russia, recent Russian regulations impose local content requirements on them. The Working Party maintains that Russia's local content regulations on multinational auto producers are a violation of the TRIMs agreement to which all WTO members must adhere.

The level of support to agriculture has been a long-standing issue in the accession of Russia. For most countries, the WTO classifies agricultural subsidies into two categories: "Amber Box" And "Green Box." Amber Box subsidies are those subsidies that are linked to production or exports, such as subsidy payments per unit of output; these are considered trade distorting and are constrained by the WTO. Green Box subsidies are those that are not considered trade distorting, and these are not constrained by the WTO; these include subsidies for research and development, pest control, extension and advisory services, inspection services for health and sanitary reasons, infrastructure services and several other categories of support to agriculture. All WTO member countries are allowed trade-distorting Amber Box subsidies up to almost 10 percent of the value of agricultural production; but trade-distorting subsidies above this amount may be permitted within negotiated limits. Thus, Russia would be permitted to support agriculture with trade-distorting subsidies up to almost 10 percent of the value of agricultural production, and maybe more depending on negotiations. Plus, it would be allowed additional unlimited agricultural support in the categories of Green Box subsidies. The worldwide trend is to move agricultural support away from trade-distorting subsidies toward Green Box measures because, in part, it is generally recognized that trade-distorting subsidies are a highly inefficient way of helping agricultural producers compared with Green Box measures.

Prospects. The next round of multilateral discussions on Russia's accession to the WTO is scheduled for the week of September 12-16, 2011. If all goes well, some or most of these remaining issues will be resolved. Negotiators are working very hard to achieve Russia's accession to the WTO at the Ministerial Conference of the WTO scheduled for December 15-17, 2011; provided the remaining issues are resolved, membership could be expected in early 2012 . 
Table 1.4: External Debt of the Corporate Sector, ${ }^{\mathrm{a}} 2010-11$

US\$ billions

\begin{tabular}{|c|c|c|c|c|c|}
\hline & January 1, 2010 & July 1, 2010 & January 1, 2011 & April 1, 2011 & July 1, 2011 \\
\hline Total debt & 421.3 & 415.6 & 442.5 & 462.0 & 485.6 \\
\hline Banks & 127.2 & 122.1 & 144.2 & 149.1 & 157.0 \\
\hline Short-term & 27.3 & 30.3 & 39.2 & 39.0 & - \\
\hline Nonfinancial corporations & 294.1 & 287.9 & 298.3 & 312.9 & 328.5 \\
\hline Short-term & 19.2 & 20.0 & 17.3 & 19.2 & - \\
\hline State and quasi-state debt & 181.3 & 181.9 & 199.6 & 203.9 & - \\
\hline
\end{tabular}

Source: CBR.

— = not available. a. Including state-owned banks and companies.

Table 1.5: External Debt of the Private Sector, ${ }^{a}$ 2010-11

US\$ billions

\begin{tabular}{lcccc}
\hline & & January 1, & January 1, & April 1, \\
\hline Banks & & $\mathbf{2 0 1 0}$ & $\mathbf{2 0 1 1}$ & $\mathbf{2 0 1 1}$ \\
& Long-term & 57.0 & $\mathbf{8 0 . 8}$ & $\mathbf{8 3 . 6}$ \\
& Short-term & 20.9 & 53.8 & 56.3 \\
Nonfinancial corporations & $\mathbf{2 0 8 . 9}$ & 27.0 & 27.3 \\
& Long-term & 190.4 & $\mathbf{2 0 8 . 6}$ & $\mathbf{2 2 2 . 4}$ \\
& Short-term & 18.5 & 191.9 & 203.9 \\
\hline
\end{tabular}

Source: CBR.

a. Including liabilities to direct investors.

LABOR MARKET — improving unemployment, rigid poverty

The labor market outcomes have been gradually improving during the first half of 2011. Economic activity and employment rates are gradually returning to the precrisis levels, but unemployment remains elevated and labor demand is lower than before the crisis. The unemployment rate has been steadily falling to reach 6.1 percent in June 2011, the lowest level since the beginning of the crisis in 2008, while slightly rising to 6.5 percent in July 2011 (figure 1.7, panel a). However, the unemployment rate is approximately 1 percentage point higher than in July 2008. The employment rate expressed as a ratio of the number of employees to the working age population has improved as well over the past several months, reaching the precrisis level of 64.6 percent in July 2011. The economic activity rate-the share of the employed and unemployed in the working age population - has reached its highest point in the past three years (69.1 percent). But the overall, favorable picture, especially compared with many developed countries, shows that the recent positive developments merely offset the absolute losses in employment associated with the economic crisis. The number of vacancies, as an indicator of labor demand, is steadily growing (figure 1.7, panel b) but is still below the precrisis level. Vacancies are increasing strongly in the large sectors such as manufacturing and finance. 
Figure 1.7 Economic activity, unemployment, and employment rates (panel a) and vacancies (panel b)
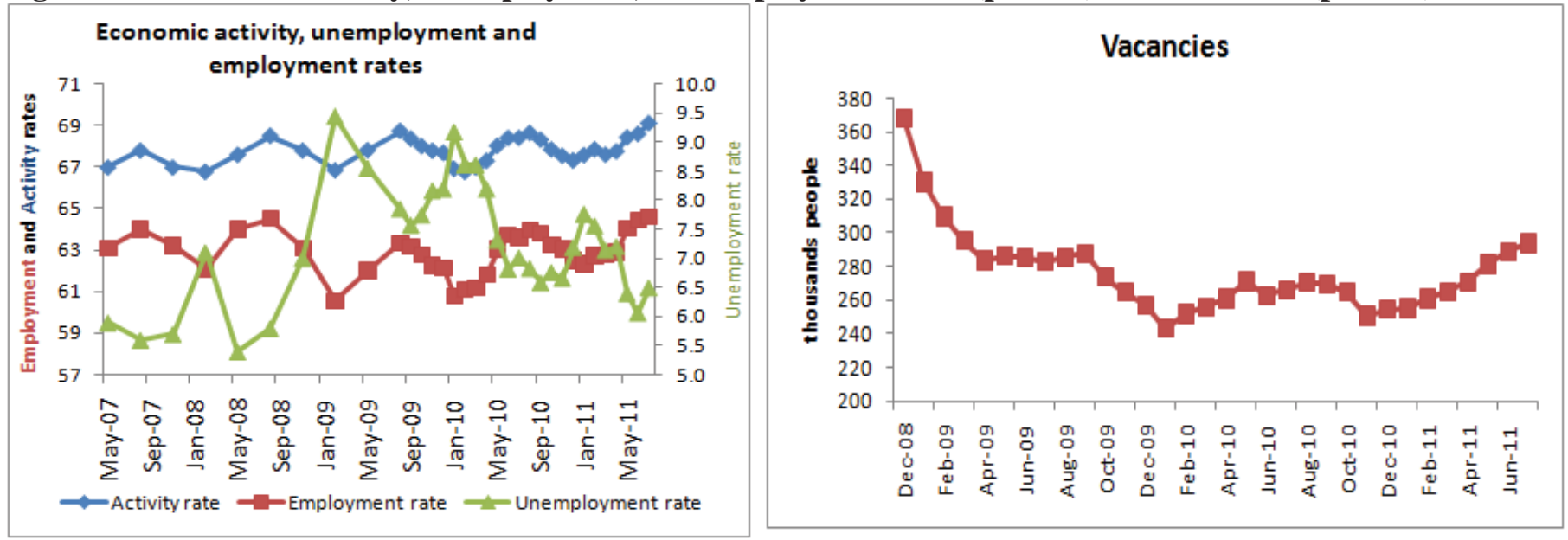

Sources: Rosstat; World Bank staff estimates.

Labor market conditions are improving across the economy, especially in finance, mining, and construction, increasingly benefitting urban areas and the male segment of the labor force. Job growth recovery is clearly observed in the construction industry, which experienced the deepest downturn in 2009. Manufacturing, energy and gas, transport, and communication show relatively lower replacement ratios. The unemployment gaps between rural and urban areas (the latter of which were harder hit by the crisis) and between males and females have returned to precrisis levels. Yet, as of July 2011, the unemployment rates among males remain about 11 percent higher than among females.

With almost two years of moderate growth, the labor market situation is now improving across all federal districts, but improvements at the regional level are much more differentiated. The unemployment rate fell in all districts in 2010 and continued to fall in the first half of 2011, especially in Moscow and St. Petersburg. But in some regions, unemployment rates remain high or have increased in comparison with the similar period of the past year. For instance, unemployment has increased in Altai republic, Chukotka autonomous okrug, Kamchatka krai, Lipetsk oblast, Mari El republic, Murmansk oblast, Smolensk oblast, Tomsk oblast, and Vladimir oblast (map 1). In some other regions, with very high rates prevailing before the crisis, unemployment remains very high, reflecting structural, investment climate, and security factors (figure 1.8). 


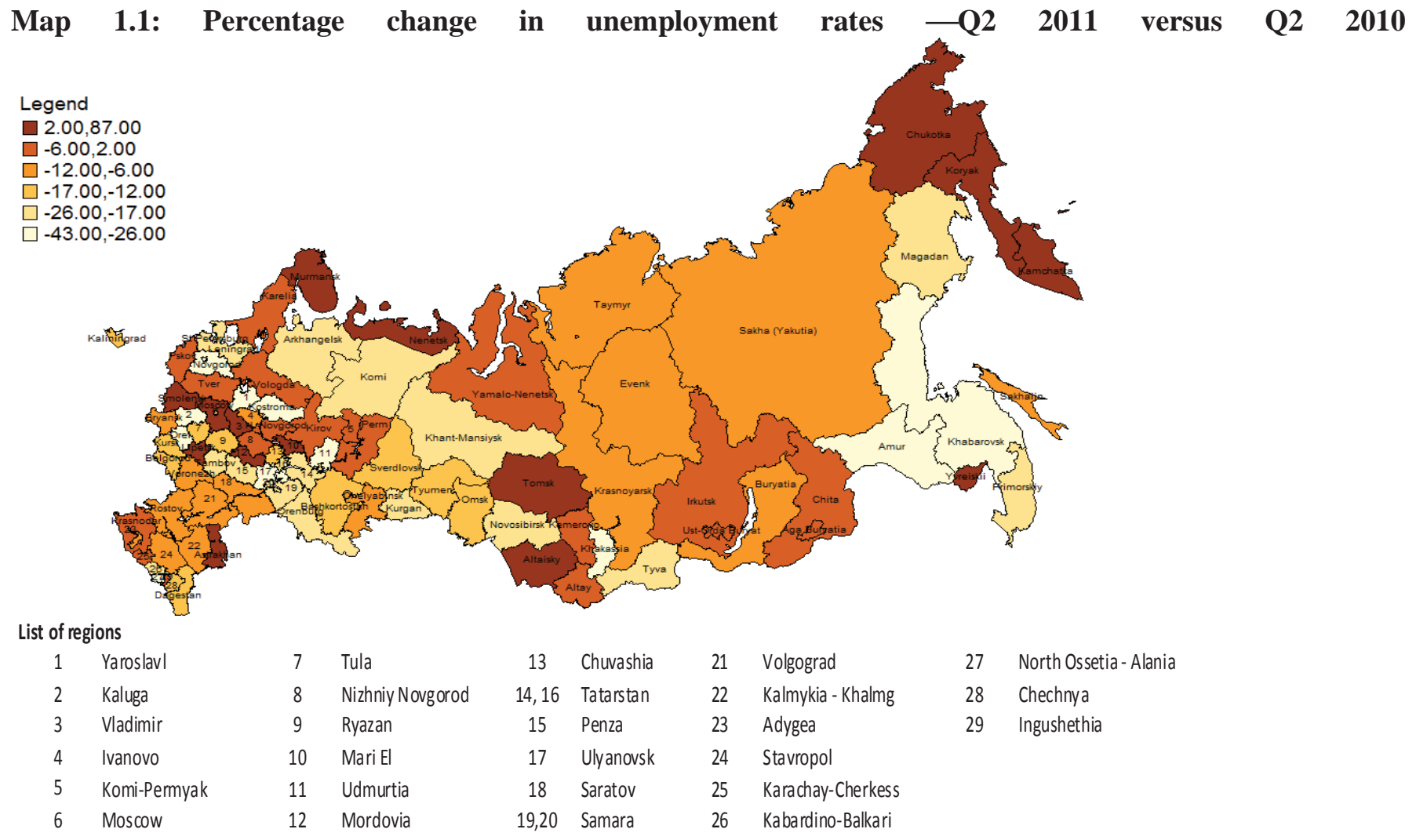

Sources: Rosstat; authors' calculations.

Figure 1.8: Unemployment Hotspots: Regions with highest unemployment rates, 2010, in percent

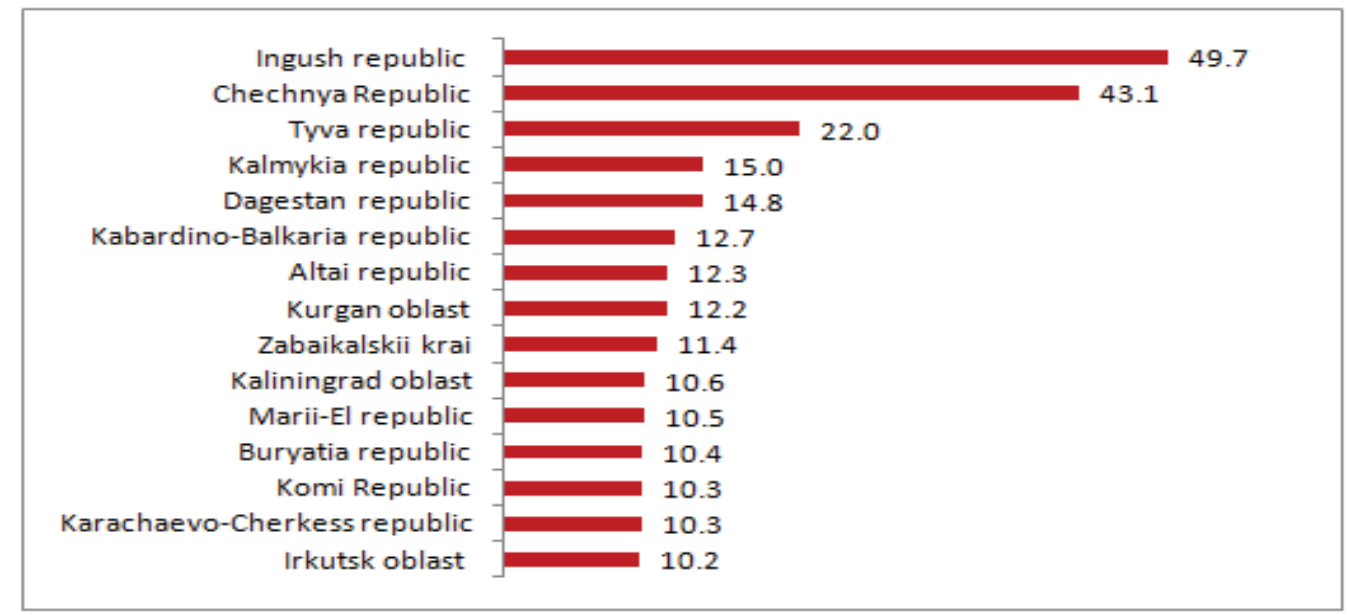

Sources: Rosstat, World Bank staff calculations.

Most regions with the highest unemployment rates are located in the North Caucasus federal district. On average, this district had an unemployment rate of 16.9 percent in 2010, more than two times higher than the country average. Two regions in the North Caucasus have the highest unemployment rates in the country: Republic of Ingushetia (49.7 percent) and Republic of Chechnya (43.1 percent). Other regions with a high level of unemployment are the Republic of Tyva (22 percent), Republic of Kalmykia (15 percent) and Republic of Dagestan (14.8 percent). In contrast, the unemployment rate in Moscow city is only 1.6 percent, and in St. Petersburg 2.6 percent; in the broader Moscow oblast, it is 3.3 percent. The 
differences in the regional levels of unemployment are striking and persistent over time, suggesting the presence of strong structural factors. As stressed in the previous Russian Economic Reports, regions with better investment climate, greater presence of small and medium-size enterprises (SMEs) and foreign direct investments (FDIs), and higher level of development tend to have lower unemployment rates.

Real wages and pensions increased slightly, along with the rise in productivity. With tightening of the labor market, private sector wages grew strongly. But despite the improvement in the labor market outcomes, non-wage, non-pension incomes (e.g., interest, rents and dividends) and public sector wages and social assistance expenditures declined slightly in real terms, resulting in a temporary, small decline in real disposable income, of 1 percent in January-July 2011, in comparison with the same period last year (figure 1.9); with continued growth in the rest of the year, however, total incomes are expected to increase. As reported by Rosstat, productivity has increased during the same period, and that bodes well for future growth, which increasingly must rely on gains in productivity. The appreciation of the ruble has pushed the average monthly dollar wage further to a new record of US\$863 per month in July 2011 (annex table).

Figure 1.9: Percentage Change in Households' Real Income, Wages, and Pensions

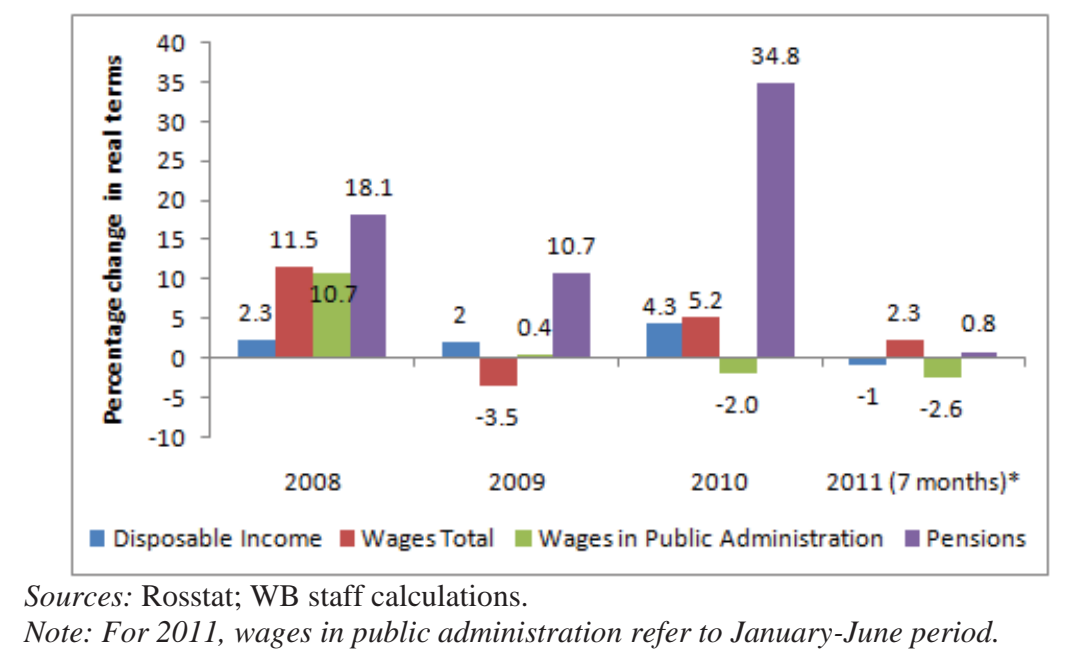

MONETARY-EXCHANGE POLICY AND CREDIT — slowing money growth and inflation

As a result of monetary tightening and capital outflows, money supply growth slowed in the first half of 2011. According to the CBR, money supply (M2) growth slowed to an average of 25.2 percent in January-July 2011 y-o-y from 33.6 percent in the same period of 2010 (figure 1.10). The CBR finished its tightening cycle in May 2011. (On May 30, CBR increased the deposit rate by 25 basis points, while keeping the policy rates and reserve requirements unchanged; see Russian Economic Report No. 25, for details). The immediate effect of the CBR's tightening measures was limited, however. Inflationary pressures continued to build until July 2011, propped up by nonmonetary factors - rising food and gasoline prices. But inflation concerns rapidly faded in July-August, following the stabilization of gasoline prices and a seasonal drop in prices on agricultural food products. Consequently, 12-month Consumer Price Index (CPI) inflation has fallen to 8.2 percent in August 2011 from 9.5 percent in June 2011, and is likely to fall below 8.0 percent by October with expected zero inflation in September. 
Figure 1.10: Money Supply Growth percent (M2, y-o-y)

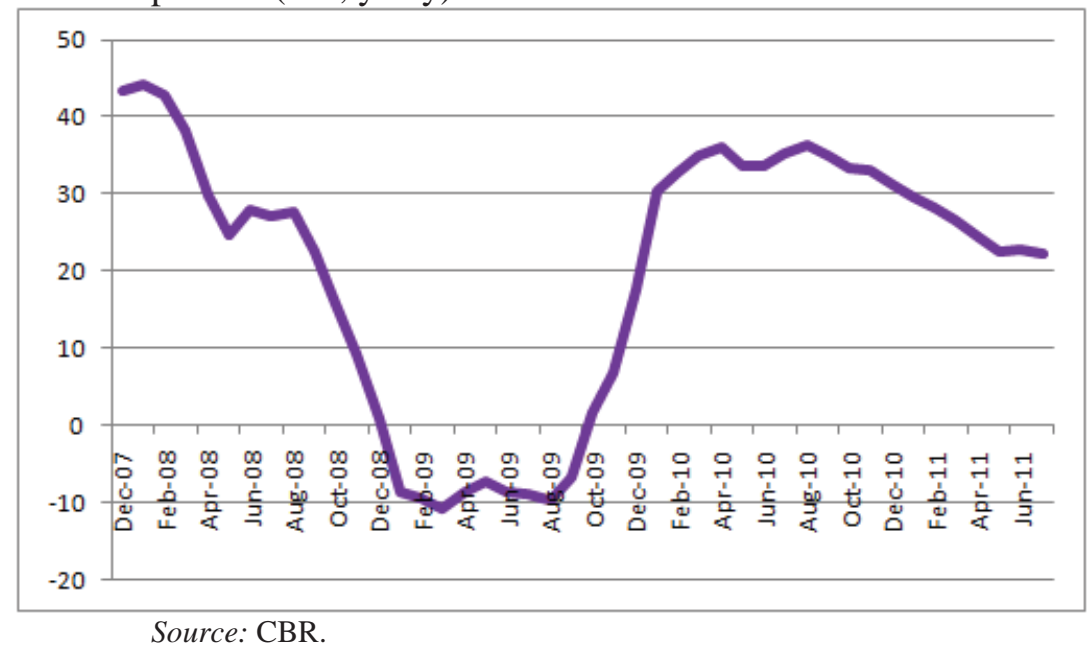

The CBR continues to tailor its exchange rate policy to the fast-changing balance of payments and macro fundamentals. This approach is reflected in a more active posture in the exchange rate market. But if during February-July 2011 the CBR was mopping up excess dollar liquidity from the market (including US\$4.6 billion of unplanned interventions), in mid-August 2011, the situation reversed, and the CBR was temporarily forced to sell U.S. dollars to smooth volatility on the market and fight off speculative attacks on the ruble.

With a continued decline in lending rates, robust credit recovery continues, but the share of total credits to the private sector in GDP remains below precrisis level. In January-July 2011, the total stock of credit to the private sector increased 19 percent in nominal terms (about 9 percent in real terms) y-o-y (figures 1.11 and 1.12). Credit to households, in particular (for example, mortgages, consumer loans and car loans), rose 25 percent during the first seven months of 2011, while credit to nonfinancial corporations increased 17.5 percent. But the share of total stock of credits in GDP remains relatively low — about 41 percent at end-July 2011 (only 10 percent for household credits). Interestingly, the average rate on consumer credits still remains at a very high level (with average spread over the refinancing rate above 1,500 basis points), while rates to enterprises dropped almost to the level of the refinancing rate. Historically, corporate lending has been a much less riskier business for Russian banks and, apparently, more competitive. 
Figure 1.11: Bank Lending Rates versus the Central Bank Policy Rate percent

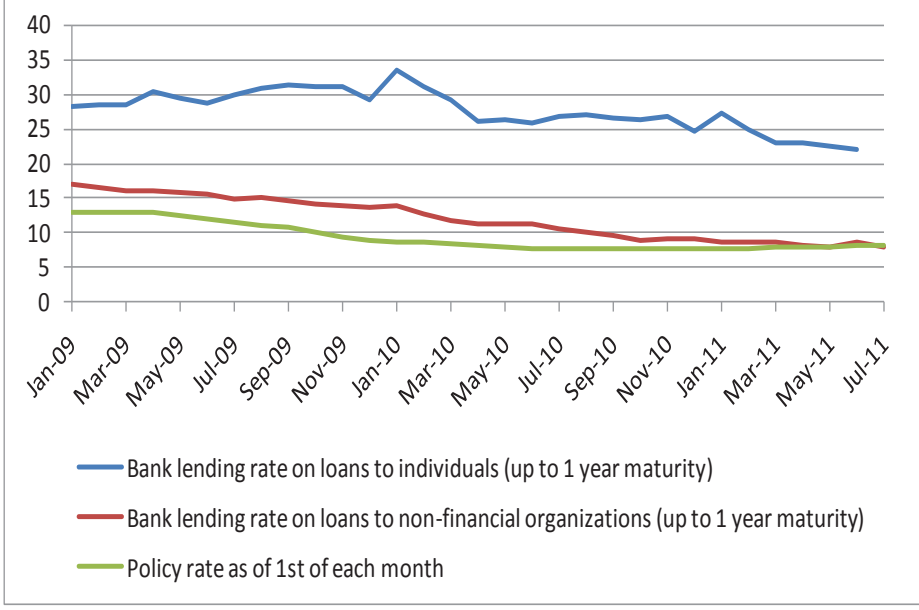

Sources: CBR; World Bank staff estimates.
Figure 1.12: Growth of Credits to the Private Sector

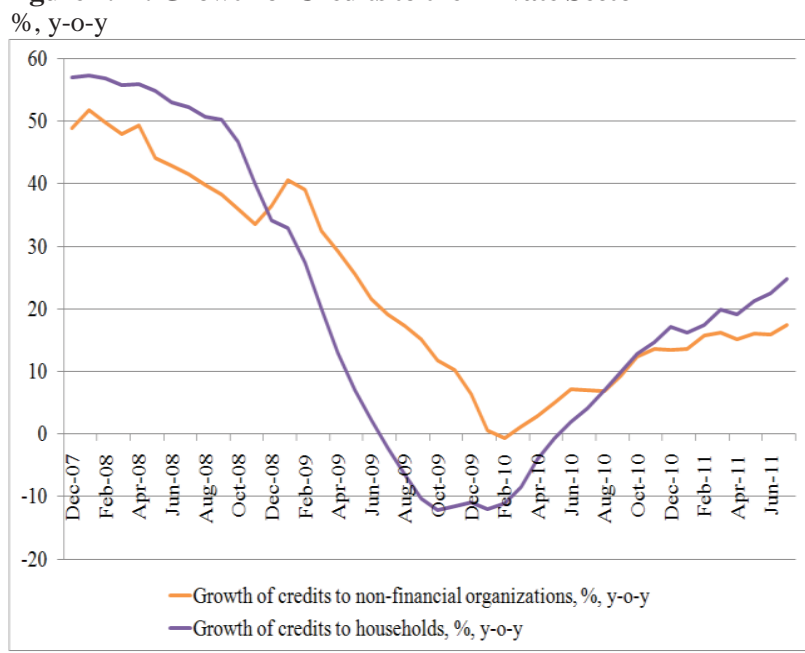

\section{FISCAL POLICY — postponing adjustment}

High oil prices and conservative expenditure execution resulted in a sizable surplus of the federal budget; this surplus, combined with the low public debt, suggests a favorable short-term fiscal outlook. According to preliminary estimates of the Ministry of Finance, the federal budget was executed with a surplus of 2.5 percent of GDP in January-July 2011 (in August 2011, the federal budget surplus increased by Rub 37 billion), compared with the 1.3 percent annual deficit stipulated in the amended 2011 budget. The surplus was mainly due to higher revenues (as a result of oil prices that average US\$117.10 per barrel of Brent in Q2 2011) that amounted to 21.8 percent of GDP compared with a targeted 19.3 percent in the Budget Law. Execution of expenditures in the first seven months of 2011 has been slow as usual, with federal spending amounting to 19.3 percent of GDP compared with 20.7 percent planned in the budget.

Notwithstanding the short-term federal budget surplus and the low public debt, the new budget plan for 2012-14 raises concerns about the long-term fiscal sustainability of Russia's public finances. Shortly after the amendment to the 2011 federal budget had been approved on May 13, 2011 (table 1.6), the government announced the new budget plan for 2012-14 (table 1.7). Against widespread expectations that the government will continue fiscal consolidation, the new parameters signify that the government is de facto postponing adjustment, at least in the next two years. According to the latest budget parameters published on September 12, 2011, the deficit of the consolidated budget and the non-oil fiscal deficit are likely to begin to drop noticeably only in 2014. This situation would mean that the widely debated introduction of an explicit fiscal rule (such as the permanent income rule; see Russian Economic Report No. 24, March 2011) would also be postponed. However, it is likely that given additional expenditure pressures, the government may maintain an interim "soft" fiscal rule that will set a cutoff price for oil above which any proceeds will be accumulated in oil funds while a deficit will be financed from domestic or foreign borrowings. 
Table 1.6: Amendment to 2011 Federal Budget

$\%$ of GDP

\begin{tabular}{|c|c|c|c|}
\hline & 2011 Federal budget) & 2011 amendment & Change \\
\hline Revenues & 17.6 & 19.3 & 1.7 \\
\hline Oil revenues & 8.1 & 9.8 & 1.7 \\
\hline Non-oil revenues & 9.5 & 9.5 & 0.0 \\
\hline Expenditures & 21.2 & 20.7 & -0.5 \\
\hline Deficit & 3.6 & 1.3 & -2.3 \\
\hline Non-oil deficit & 11.7 & 11.1 & -0.6 \\
\hline
\end{tabular}

Source: Ministry of Finance, Economic Expert Group.

Table 1.7: Preliminary Medium-Term Budget Parameters in 2012-14

$\%$ of GDP

\begin{tabular}{rccc}
\hline & $\mathbf{2 0 1 2}$ & $\mathbf{2 0 1 3}$ & $\mathbf{2 0 1 4}$ \\
\hline Consolidated budget 1/ & & & \\
Revenues & 37.1 & 36.6 & 36.1 \\
Expenditures & 39.1 & 38.4 & 37.0 \\
Surplus (+)/Defici (-) & -1.9 & -1.8 & -0.9 \\
\hline Federal budget 2/ & & & \\
Revenues & 20.1 & 19.6 & 19.5 \\
Expenditures & 21.6 & 21.2 & 20.2 \\
Surplus(+)/Deficit (-) & -1.5 & -1.6 & -0.7 \\
Non-oil surplus & -11.0 & -10.3 & -9.2 \\
(+)/deficit (-) & &
\end{tabular}

Source: Ministry of Finance, Economic Expert Group.

1/ Estimates of the World Bank staff based on published budget parameters.

2/ Ministry of Finance preliminary budget parameters published on September 12, 2011. 


\section{ECONOMIC AND SOCIAL OUTLOOK FOR RUSSIA, 2011-12}

Summary: With heightened risks to global growth and lower commodity prices, we now expect Russia's real GDP to grow 4 percent in 2011 (down from 4.4 percent expected in June) because of the lower Q2 outcome and the impact on domestic demand of the external conditions. Unemployment is expected to remain under 7 percent but as the activity returns to the pre-crisis level, further reduction in unemployment will be slow. Although the aggregate, short-term unemployment picture is favorable, unemployment remains very high in many regions, especially in the North Caucasus federal district, reflecting, investment climate and structural factors. Regions with better investment climate, greater presence of SMEs, and FDIs and higher income typically have lower unemployment rates. After five years of stable poverty, with more moderate growth than before the crisis, further gains in poverty will be more difficult, requiring improved effectiveness of public expenditures and better targeting of social programs.

Global growth is now projected to slow in the face of significant market turbulence, slowdown in the United States and European Union, and associated uncertainties. After expanding 3.8 percent in 2010, global GDP is now projected to slow to 2.8 percent in 2011 before firming to 3.2 percent in 2012 (table 2.1). Lower-than-expected growth in the United States and the EU in the first half of 2011, renewed financial and debt pressures, after effects of the earthquake in Japan, and an increasing degree of fiscal policy tightening are projected to reduce growth in high-income countries to 1.6 percent in 2011, down from 2.7 percent in the previous year. This will also remove demand pressure from oil markets, allowing prices to ease from recent highs. (figure 2.1; and section III of this report on the world oil market). Assuming that the U.S. economy and the European debt crisis do not deteriorate further in the rest of 2011, in 2012, global growth is expected to rise to 3.2 percent and beyond as the negative effects of ongoing instability subside and the positive effects from rebuilding in Japan intensify. As countries close their output gaps, aggregate growth in developing economies is also projected to ease.

Table 2.1: GDP Growth: Summary of the Global Outlook percent

\begin{tabular}{lcccc}
\hline & $\mathbf{2 0 0 9}$ & $\mathbf{2 0 1 0}$ & $\begin{array}{c}\mathbf{2 0 1 1} \\
\text { (projected) }\end{array}$ & $\begin{array}{c}\mathbf{2 0 1 2} \\
\text { (projected) }\end{array}$ \\
\hline World & -2.2 & 3.8 & 2.8 & 3.2 \\
High-income countries & -3.4 & 2.7 & 1.6 & 2.2 \\
Developing countries & 1.9 & 7.4 & 6.0 & 6.0 \\
Russian Federation & -7.8 & 4.0 & 4.0 & 3.8 \\
\hline Sources: World Bank staff. & & & &
\end{tabular}


Figure 2.1: Cooling Oil: World Bank Oil Price Forecast for Average

Crude: Brent, Dubai, and West Texas Intermediate (WTI)

simple average, US\$/barrel

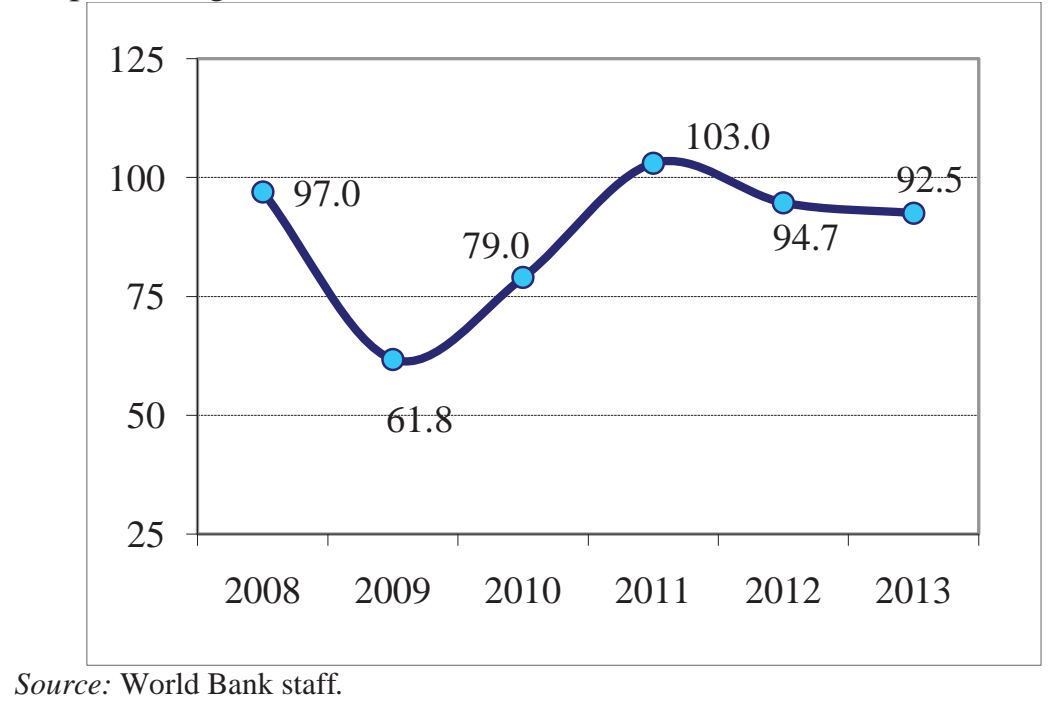

In the environment of heightened uncertainties and a slowdown in the U.S. and major European economies, Russia's real GDP growth in 2011 has been revised downward (table 2.2; figure 2.2). But despite the negative impact from the slowdown in global demand on tradables (especially manufacturing) in Russia, the still relatively high oil price and low unemployment will help sustain robust growth in domestic consumption, which, in turn, will support overall growth during the second half of 2011.

As documented in the earlier Russian Economic Report No. 24 (March 2011), Russia's direct trade exposure to the highly indebted European countries is limited, which will diffuse the impact of a possible deteriorating debt crisis through the trade channel; financial channel is also relatively muted (box 2.1). As a result, we now expect the Russian economy to grow 4.0 percent in 2011, down from 4.4 percent projected in the Russian Economic Report No. 25, June 2011 (RER 25). In 2012, with the closing of the output gap, the end of the inventory restocking cycle, and lower oil prices, external and domestic demand could be somewhat affected, slightly lowering projected growth to 3.8 percent. The unemployment situation is expected to improve, gradually converging to what are more stable, mediumterm unemployment rates in the 6-6.5 percent range (figure 2.3).

Table 2.2: Outlook for Russia, 2011-12

\begin{tabular}{|l|c|c|}
\hline & $\mathbf{2 0 1 1}$ & $\mathbf{2 0 1 2}$ \\
\hline GDP growth (\%) & 4.0 & 3.8 \\
\hline Consolidated government balance (\%) & -0.2 & -1.6 \\
\hline Current account (US\$ billions) & 67.0 & 21.0 \\
\hline Percentage of GDP & 3.8 & 1.1 \\
\hline Capital account (US\$ billions) & -30. & -6 \\
\hline Percentage of GDP & -1.7 & -0.3 \\
\hline Oil price assumption (US\$ per barrel) & 103.0 & 94.7 \\
\hline
\end{tabular}

Source: World Bank staff projections. 
The balance of payments position is expected to deteriorate toward end-2011, while capital flows are likely to remain volatile, reflecting increased global uncertainties. Under the revised forecast of oil prices, we expect the surplus on the external current account to amount to about US\$67 billion in 2011 (about 3.8 percent of GDP) and then to deteriorate to US\$21 billion in 2012. The capital account is projected to slightly deteriorate in 2011 to a deficit of US\$30 billion. In the baseline scenario for 2012, the capital account is projected to show some improvement to a deficit of US\$6 billion as a result of gradually improving global conditions in 2012, the return of nondebt capital inflows, lower debt repayments, and improved borrowing capacity of banks and nonfinancial corporations under the baseline scenario. However, downside risks to the global conditions and capital account-associated with increasing global uncertainties and a possible sharp drop in oil prices_-remain.

Given the new oil price assumptions and draft budget parameters for 2011-12, we revised our projections for Russia's consolidated budget downward. According to our latest estimates, the consolidated budget would be balanced in 2011 and show a deficit of 1.6 percent in 2012. However, we believe that significant downside risks are associated with global demand and highly volatile oil prices (for some illustrative scenarios, see box 2.1) and new expenditure pressures from the planned modernization of the army, spending on infrastructure, and additional social spending, especially during the election period.

Figure 2.2: Demand Sources of Russia's Real Growth, by Quarter, 2008-11

\% change, $\mathrm{y}-\mathrm{0}-\mathrm{y}$

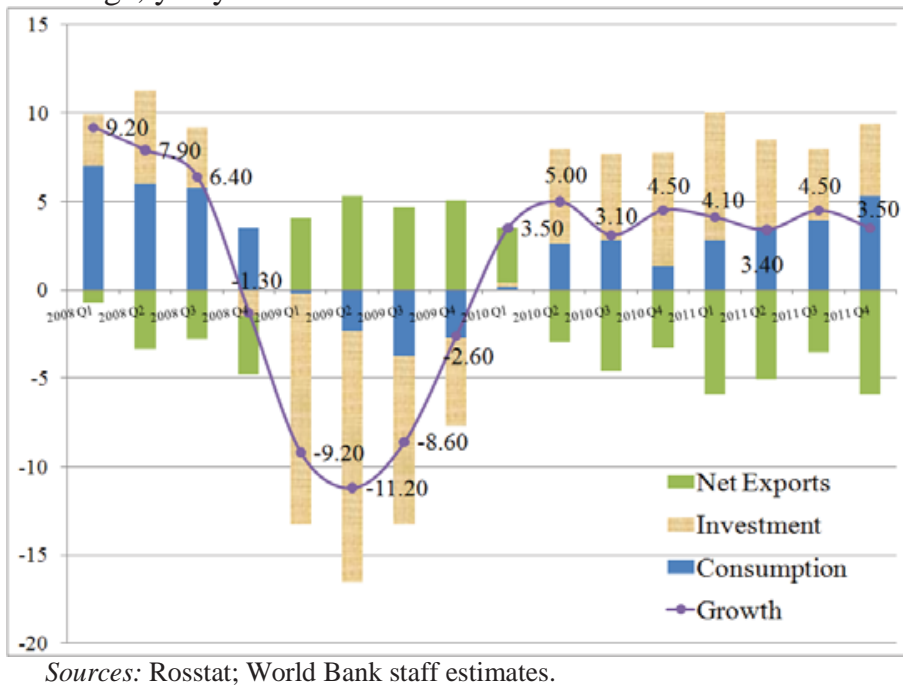

Figure 2.3: Monthly Unemployment Rate Dynamics in Russia, 1999-2011

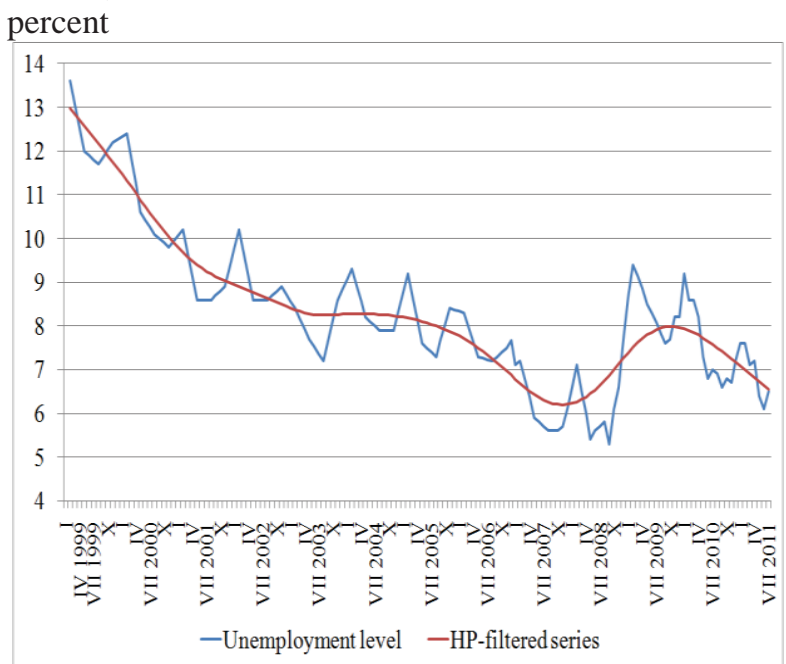

Sources: Rosstat; World Bank staff estimates.

Box 2.1: Thinking Through Downside Scenarios: How Bad Can it Get in Russia?

The sharply rising uncertainties in the global economy call for thinking through alternative scenarios and their implications for the Russian economy. We explored two, mainly illustrative scenarios, to underscore the vulnerability of the Russian economy to a new drop in global oil demand and to emphasize the need for smart medium-term fiscal adjustment that includes significant improvements in the effectiveness of public spending and better targeting of the social programs.

At the outset, it is worth mentioning that the Russian economy has very limited, direct exposure to the Greek crisis because of its limited trade with Greece and other highly indebted European countries and also because the Russian banks' have a very small exposure to European sovereign securities of highly indebted countries. As a result, direct trade and financial sector channels of contagion to the Greek crisis are fairly muted. However, the indirect effect of a broader economic deterioration in Europe could still be substantial, working primarily through the traditional channels of transmission of external shocks to Russia - oil prices and capital flows and, depending on the severity of 
the shocks, financing and liquidity effects.

Using the results of the empirical model discussed in Box 1.1, we have performed a forward-looking scenario analysis for consumption, growth and unemployment under two additional scenarios beyond the baseline in this Outlook: "moderate shock" scenario and "severe shock" scenario to explore the implications of lower oil prices and growth on consumption, unemployment, and fiscal balance. In view of the global uncertainties, such an illustrative exercise could be useful in thinking through the likely consequences of both a moderate deterioration in the global and the Russia outlook and a severe deterioration that could be associated with a recession in some of the largest high-income countries and significant worsening of the European debt crisis.

Under the "moderate shock" scenario, global growth outlook gradually deteriorates, reflected in lower oil price outlook to an average of US\$80 (a drop of about US $\$ 15$ compared with the baseline outlook). (Note that this is not an improbable scenario given that US\$80 in real terms is the current, long-term equilibrium level of oil prices according to the World Bank commodity forecasts; it would also be much more favorable than during the crisis 2009 when the World Bank oil price index averaged just above US\$60 per barrel). This results in the growth in 2011 and the fiscal balance and unemployment all being adversely affected in the last quarter of the year with moderate impact on the year as a whole (box table 2.1). But in 2012, growth is cut by 2 percentage points and, without corrective adjustment, fiscal balance deteriorates sharply to 3.1 percent of GDP. The remaining balances of the Reserve Fund would likely be used to partly finance the gap with the remainder likely to come from domestic financing. Unemployment would trend back to 7 percent.

Finally, under the "severe shock" scenario, global outlook is severely affected by the recession in one of the major economic blocks, resulting in a sharp contraction in global demand and demand for oil. Under these conditions, oil demand would fall sharply and prices could again average US\$60 in 2012 (as in 2009). Russia's economy would also enter a recession with negative growth and unemployment rising almost 1.5 percentage points higher than in the baseline outlook. Absent countervailing fiscal measures, fiscal balance would turn into a deficit of about 5.3 percent of GDP. Both scenarios would require significant, new fiscal measures consisting of tax, expenditure, and financing measures to close the resulting fiscal gaps.

Box table 2.1: Simulation Results for Consumption Growth in Russia, 2011-12

Scenario 1 (base case)

\begin{tabular}{|c|c|c|c|c|c|}
\hline & $\begin{array}{c}\text { Oil price (Brent), } \\
\text { USD/bbl }\end{array}$ & $\begin{array}{c}\text { GDP growth } \\
\mathrm{y}-\mathrm{o}-\mathrm{y}, \%\end{array}$ & $\begin{array}{c}\text { GG surplus/deficit, } \\
\% \text { GDP }\end{array}$ & $\begin{array}{c}\text { Unemployment } \\
\text { rate, \% }\end{array}$ & $\begin{array}{c}\text { Consumption growth } \\
\mathrm{y}-\mathrm{o}-\mathrm{y}, \%\end{array}$ \\
\hline 2011 & 105 & 4.0 & -0.2 & 6.6 & 5.5 \\
\hline 2012 & 95 & 3.8 & -1.6 & 6.3 & 5.3 \\
\hline
\end{tabular}

Scenario 2 (moderate shock)

\begin{tabular}{|c|c|c|c|c|c|}
\hline & $\begin{array}{c}\text { Oil price (Brent), } \\
\text { USD/bbl }\end{array}$ & $\begin{array}{c}\text { GDP growth } \\
\text { y-0-y, \% }\end{array}$ & $\begin{array}{c}\text { GG surplus/deficit, } \\
\% \text { GDP }\end{array}$ & $\begin{array}{c}\text { Unemployment } \\
\text { rate, \% }\end{array}$ & $\begin{array}{c}\text { Consumption growth } \\
\text { y-o-y, \% }\end{array}$ \\
\hline 2011 & 100 & 3.5 & -0.5 & 6.8 & 5.0 \\
\hline 2012 & 80 & 2.0 & -3.1 & 7.0 & 3.0 \\
\hline
\end{tabular}

Scenario 3 (severe shock)

\begin{tabular}{|c|c|c|c|c|c|}
\hline & $\begin{array}{c}\text { Oil price (Brent), } \\
\text { USD/bbl }\end{array}$ & $\begin{array}{c}\text { GDP growth } \\
\text { y-0-y, \% }\end{array}$ & $\begin{array}{c}\text { GG surplus/deficit, } \\
\% \text { GDP }\end{array}$ & $\begin{array}{c}\text { Unemployment } \\
\text { rate, \% }\end{array}$ & $\begin{array}{c}\text { Consumption growth } \\
\mathrm{y}-\mathrm{0}-\mathrm{y}, \%\end{array}$ \\
\hline 2011 & 90 & 3.3 & -1.4 & 7.0 & 4.6 \\
\hline 2012 & 60 & -1.5 & -5.3 & 7.5 & 0.3 \\
\hline
\end{tabular}

Source: WB staff calculations.

What will happen to consumption? Interestingly, the simulations show that the pattern of consumption in Russia is expected to remain resilient to negative shocks, consistent with a significant consumption-smoothing effect. As a result, we expect consumption growth to remain higher than GDP growth in 2011-12. If internal and external conditions remain as in the baseline of the outlook of the report (that is, GDP growth remains in the 4 percent range, oil prices stay at around US $\$ 100 /$ barrel, and the unemployment rate decreases slightly; then consumption growth remains practically unchanged in 2012. In the case of moderate and severe oil shocks (moderate and severe shock scenarios, respectively) and the consequent slowdown of the Russian economy and lower demand for labor, consumption growth is projected to slow moderately. Yet we expect consumption growth to remain positive, even in the case of a recession (scenario 3), on the strength of the smoothing effect. The expected recovery of household demand following the negative shocks is likely to be slower than for investment or external demand. 
Given the current trends and policies, we expect inflationary pressures to diminish somewhat faster than we projected in RER 25. Slower growth in money supply, easing of global commodity prices, and a strong global grain harvest are currently exerting a downward (albeit mainly seasonal) pressure on food prices in Russia. As a result, we now expect somewhat lower CPI inflation in 2011-about 7.5 percentthan as projected in RER 25-between 7.5 and 8 percent. We keep our projection for 2012 in the range of 6 to 7 percent, taking into account additional risks for inflation associated with possible monetary factors and additional fiscal spending during the election cycle. The overall balance of macroeconomic risks has shifted toward economic growth.

Russia's national poverty rate during the difficult years of 2009 and 2010 was essentially flat, and the government managed to cushion the effect on the poor through a large fiscal stimulus, but poverty reduction going forward will be more difficult. The recent growth rebound and improvement in the labor market outcomes is yet to translate into tangible poverty reduction. As a result, the aggregate poverty rate will change only marginally in 2011 compared with the precrisis rate in 2007. This means an unchanged poverty level for the fifth consecutive year, underlying the gravity of the remaining poverty problem in Russia. The real income of the population fell in the first seven months of 2011, and reported poverty in the first quarter was, in fact, higher than in the same period last year. The lack of intervening indexation of the public sector wages and social expenditures and the relatively high inflation rate in the first half of 2011 reduced some of the gains that low-income families obtained from the stimulus package introduced during the crisis period. Consequently, both real wages in the public sector and total income of the population declined marginally in real terms in the first seven months of 2011. Thus, we now project a slightly more gradual pace of poverty reduction for the coming years than projected in the previous RERs (figure 2.4).

Figure 2.4: Poverty Rate and Level in Russia, 2006-12

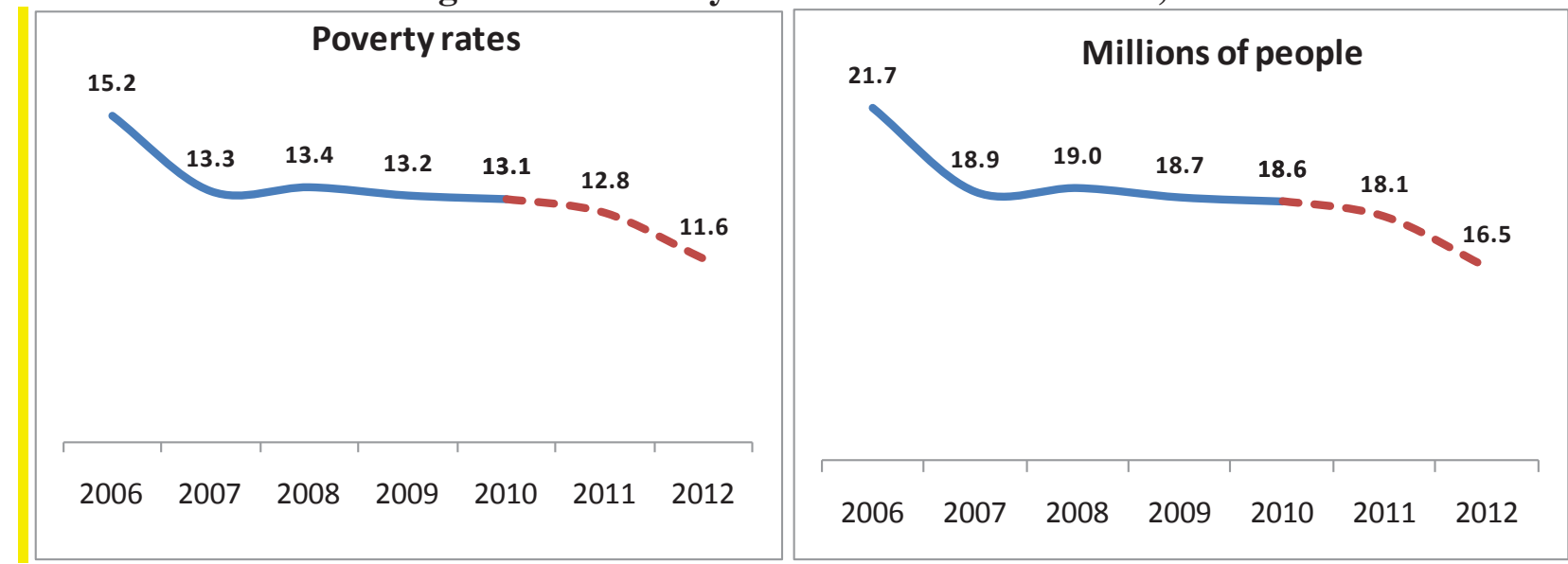

Sources: Rosstat, actual data for 2006-10; RER team calculations based on Household Budget Survey data and projections for 2011-12. 


\section{The World OIL MARKeT: DeVelopments ANd Prospects}

Summary. In the face of the slowdown in global growth, the oil market has swung from a period of perceived overtightening to one of heightened concerns about slowing oil demand and downside risks to oil prices. This technical note reviews recent oil market developments and prospects with the view to providing a more nuanced picture of the complex factors driving this major global commodity market, which exerts significant impact on the Russian economy.

\section{Oil Market Developments}

In 2011, the oil market has swung from a period of perceived overtightening to one of heightened concerns about slowing oil demand. Oil prices (World Bank average; see figure 3.1) rose to a high of US\$120 per barrel (bbl) in April, following the loss of 1.3 million barrels per day (mb/d) of Libya's light/sweet crude and smaller disruptions elsewhere, for example, in Yemen. The price increase also occurred during a sustained period of strong demand $(2.3 \mathrm{mb} / \mathrm{d}$ or 2.6 percent in the first quarter following large growth of $3 \mathrm{mb} / \mathrm{d}$ or 3.5 percent in H2 2010). Since then, prices have fallen as demand has waned, supplies have increased, and investor confidence has eroded amidst fears of further economic weakness.

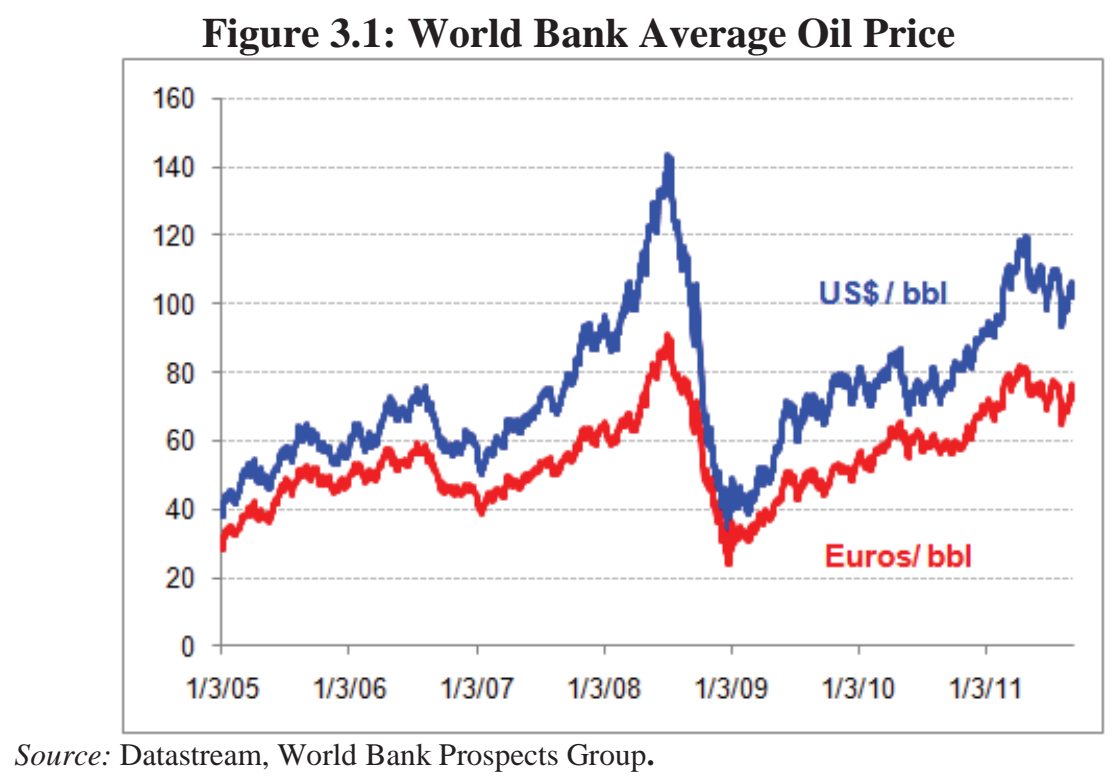

Regarding oil demand, at US $\$ 120 / \mathrm{bbl}$, oil prices were returning to levels that affect end-use demandmainly for transport fuels, and especially in the United States where demand is again contracting - and across most Organisation for Economic Co-operation and Development (OECD) countries. At the same time, global economic activity has slumped and global oil demand growth slowed sharply in the second quarter of 2011 to $0.6 \mathrm{mb} / \mathrm{d}$ or 0.7 percent; of this, OECD oil demand fell $0.9 \mathrm{mb} / \mathrm{d}$ or 2 percent, while non-OECD demand rose $1.5 \mathrm{mb} / \mathrm{d}$ or 3.5 percent.

On the supply side, oil production by Organization of Petroleum Exporting Countries (OPEC) rose by more than $1 \mathrm{mb} / \mathrm{d}$ in June/July, mainly spurred by a large unilateral increase by Saudi Arabia, but also as a result of increases in the United Arab Emirates, Angola, and the República Bolivariana de Venezuela. OPEC oil ministers met in mid-June but could not agree on any change to oil production targets or on the way to address the loss of Libya's oil output. The International Energy Agency (IEA) responded by 
releasing 60 million barrels of oil from strategic reserves, half of which were physical volumes from the U.S. Strategic Petroleum Reserve. Although much of the remaining $30 \mathrm{mb}$ were in the form of relaxation of stock-holding requirements in Europe and Japan, most of the physical barrels were reaching markets in August. A major development in oil pricing in 2011 has been the substantial widening of prices between West Texas Intermediate (WTI) and Brent (figure 3.2). The price of WTI (a landlocked U.S. domestic crude) has fallen as much as US\$27/bbl or 24 percent below internationally traded Brent (compared with a small premium for quality reasons historically). The slump in WTI prices is due to a buildup of crude in the U.S. mid-continent because of increased flows from Canada and higher production from shale rock in North Dakota. There is limited outlet from the mid-continent to the U.S. Gulf coast and international markets, and thus stock levels ebb and flow with the seasonal pace of refining runs. Because of the large WTI discount, some crude has been moving out of the region by rail and truck, and inventories in the midcontinent have actually fallen somewhat from earlier highs. JP Morgan reports that a US\$24/bbl discount is necessary to ship crude from Cushing, Oklahoma, to St. James, Louisiana, using alternate transport. In addition, refiners in the region have postponed maintenance to facilities and are maintaining crude demand, as they profit from large discounted crude costs. However, a large discount for WTI is expected to remain - to help facilitate crude shipments by alternative methods - until new pipelines are built to the U.S. Gulf coast (2013) or from Alberta, Canada, to the Pacific coast (2015). This situation also has implications for Russian oil — the Urals (see below).

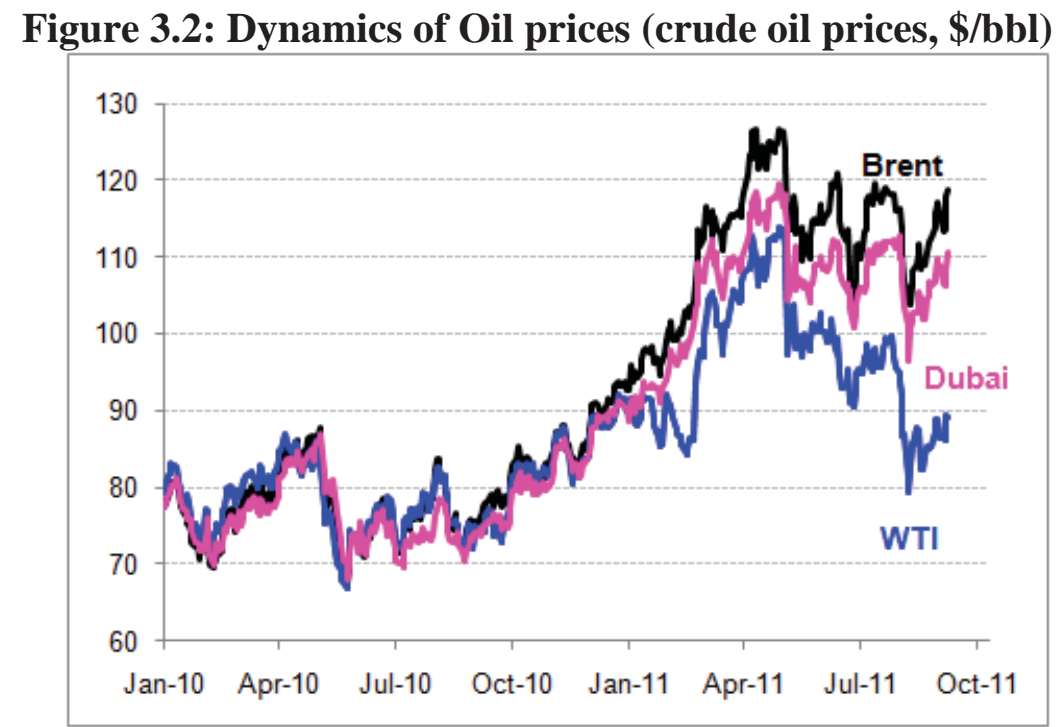

Source: Datastream, World Bank Prospects Group.

Despite oil demand weakness and U.S. domestic surplus, international crude oil markets are relatively firm. Stocks have fallen closer to their five-year range, and prices are being supported from the continued loss of Libyan light/sweet crude, other disruptions (for example, Nigeria), and fears of further geopolitical and technical dislocations in the market. Demand in emerging markets remains strong-albeit slowingnotably in China but also in Saudi Arabia and Latin America. In addition, nuclear outages in Japan are adding $0.25 \mathrm{mb} / \mathrm{d}$ to oil demand for power generation.

OPEC's spare capacity has continued to fall, from $6.5 \mathrm{mb} / \mathrm{d}$ at the beginning of 2010 to less than $4.0 \mathrm{~m} / \mathrm{d}$ in July (figure 3.3). The IEA gauges the effective surplus in the four main Gulf countries-Saudi Arabia, Kuwait, Qatar, and the United Arab Emirates - at only $2.7 \mathrm{mb} / \mathrm{d}$. Much of the spare capacity is mediumsour crude, thus making it difficult to replace lost light/sweet crude. 


\section{Figure 3.3: OPEC Spare Capacity (mb/d)}

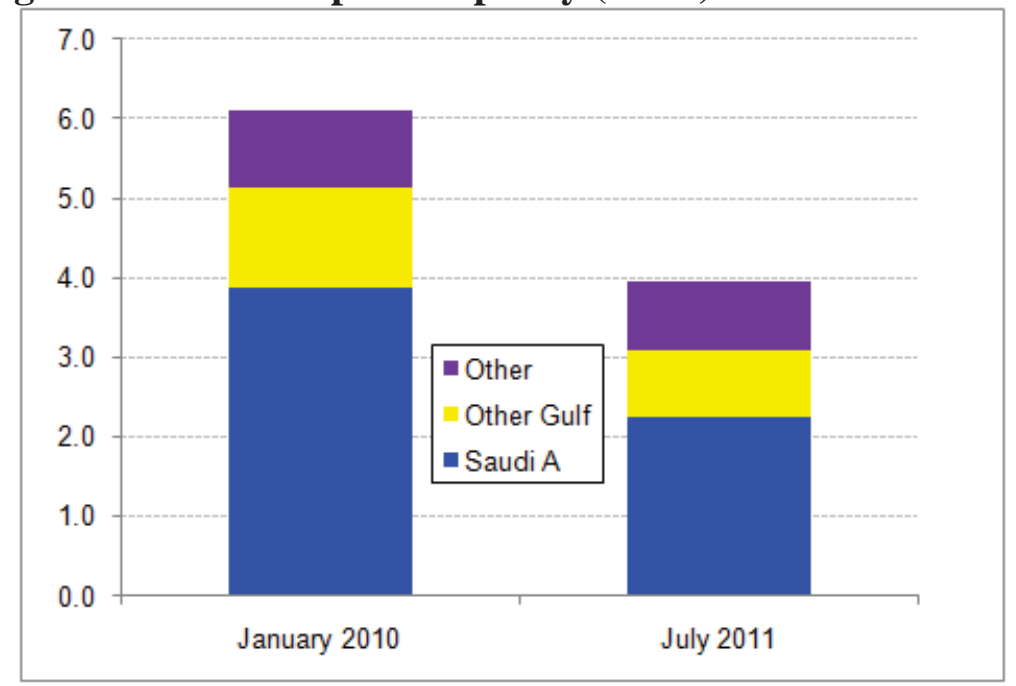

Source: International Energy Agency, Oil Market Report.

\section{Libyan Oil}

With an imminent end to conflict in Libya, there is much speculation as to how soon oil production will resume in Libya, and when it might return to previous full production of about $1.6 \mathrm{mb} / \mathrm{d}$. The former chairman of the National Oil Corporation and de facto oil minister, Shokri Ghanem, stated that production may restart at $0.3-0.4 \mathrm{mb} / \mathrm{d}$ initially and rise to $1 \mathrm{mb} / \mathrm{d}$ in a year's time and to full production within two years. Many analysts expect a similar rebound, although some believe full production is possible by end2012. A leading expert stated Libya may take three years to reach full output while Iraq took five years to return to prewar levels of production.

A number of obstacles must be overcome before Libya's oil production can restart-most important, the eventual structure of the transition government and oil sector. A prolonged power struggle could delay the process. The country relies on foreign technical workers, and they cannot return until conditions are safe and politically stable. In addition, there are reports of damage to pipelines, oil production facilities, and infrastructure, and desert work camps have been looted. An assessment of the damage must be made, including possible well workovers and repairs to infrastructure, before significant volumes of oil can flow. It is assumed that $0.2-0.4 \mathrm{mb} / \mathrm{d}$ of crude will be restarted by end-2011, and $1 \mathrm{mb} / \mathrm{d}$ by end-2012. Gas shipments to Italy could begin sooner, although currently, Italy is oversupplied with gas.

\section{Global Oil Price Outlook}

The World Bank oil price forecast has been revised down to US $\$ 103.00 / \mathrm{bbl}$ in 2011 , US\$94.70/bbl in 2012, and US\$88.50/bbl in 2015 (table 3.1). The forecast assumes a gradual resumption of oil production in Libya, with output reaching $1 \mathrm{mb} / \mathrm{d}$ by end-2012 in the baseline scenario. Global supply risks remain from further geopolitical turmoil and outages, including a slow, lengthy recovery in Libya. In contrast, downside risks exist for oil demand from slower economic growth and still-high oil prices. A key element for price stability will be how OPEC responds to higher or lower demand for its crude. 
Table 3.1: Crude oil price forecast, US\$/bbl

\begin{tabular}{lrrrrrr} 
& $\mathbf{2 0 1 0}$ & $\mathbf{2 0 1 1}$ & $\mathbf{2 0 1 2}$ & $\mathbf{2 0 1 3}$ & $\mathbf{2 0 1 4}$ & $\mathbf{2 0 1 5}$ \\
\hline World Bank average & $\mathbf{7 9 . 0}$ & $\mathbf{1 0 3 . 0}$ & $\mathbf{9 4 . 7}$ & $\mathbf{9 2 . 5}$ & $\mathbf{9 0 . 5}$ & $\mathbf{8 8 . 5}$ \\
Brent & 79.6 & 110.6 & 101.2 & 98.0 & 95.2 & 91.5 \\
WTI & 79.4 & 93.2 & 86.7 & 86.0 & 85.2 & 86.5 \\
Dubai & 78.1 & 105.2 & 96.2 & 93.5 & 91.0 & 87.5 \\
Urals & 78.3 & 108.7 & 99.0 & 95.5 & 92.7 & 89.0
\end{tabular}

Source: World Bank, DEC Prospects Group.

Global oil demand in 2011 is expected to rise by $1.2 \mathrm{mb} / \mathrm{d}$ or 1.4 percent according to the IEAincluding a $0.3 \mathrm{mb} / \mathrm{d}$ decline in the OECD countries. For 2012, the IEA projects an increase of $1.6 \mathrm{mb} / \mathrm{d}$ or 1.8 percent-near trend growth and with all the gain in the non-OECD countries. Given current weak economic conditions and outlook, OECD oil demand could again contract in 2012 and global oil demand growth could be similar to the 2011 estimate.

Non-OPEC supplies continue to surprise to the upside, despite a number of disruptions, because of continuing large investments in the sector. In the second half of 2011, non-OPEC production is expected to jump $1 \mathrm{mb} / \mathrm{d}$ from H1 2011 as a result of new-field growth of $0.6 \mathrm{mb} / \mathrm{d}$ and resumption from earlier outages and from maintenance in the North Sea, Canada, and elsewhere. Non-OPEC supplies are projected to increase by $1 \mathrm{mb} / \mathrm{d}$ in 2012, with large gains in Brazil, Canada, Australia, China, and from biofuels. Moderate growth is expected to continue over the forecast period. OPEC crude oil production is expected to increase only modestly in 2012 from its current level of $30 \mathrm{mb} / \mathrm{d}$ and may, in fact, record zero gain if demand is lower than projected. In such a case, as Libya's oil production recovers, the group will have to accommodate by lowering output among other members to prevent downward pressure on prices. Over the medium term, OPEC producers are expected to absorb a portion of the moderate growth in global oil demand. This will erode surplus capacity only modestly, because most countries are investing in new capacity.

\section{Price Differentials}

With the collapse of WTI as an international benchmark, Brent has emerged as the most important marker crude, particularly for the pricing of Urals oil, which is particularly relevant for Russia (figure 3.4). The discount of Urals to Brent has narrowed significantly this year, with Urals priced close to par with Brent in late August. A few factors have contributed to its price strength. Russia's refining runs have increased twice as fast as the growth in crude production this year, thus reducing export volumes. In addition, exports have been increasingly moving to Asian markets through the Eastern Siberian-Pacific Ocean pipeline, which is reducing supplies to the Mediterranean and European markets. Finally, European refiners have been adding upgrading capacity to existing facilities, thereby improving their ability to handle heavier grades. The switch to heavier grades has been enhanced by the loss of light/sweet crude. 
Figure 3.4: Brent, Dubai, WTI and Urals Oil Prices

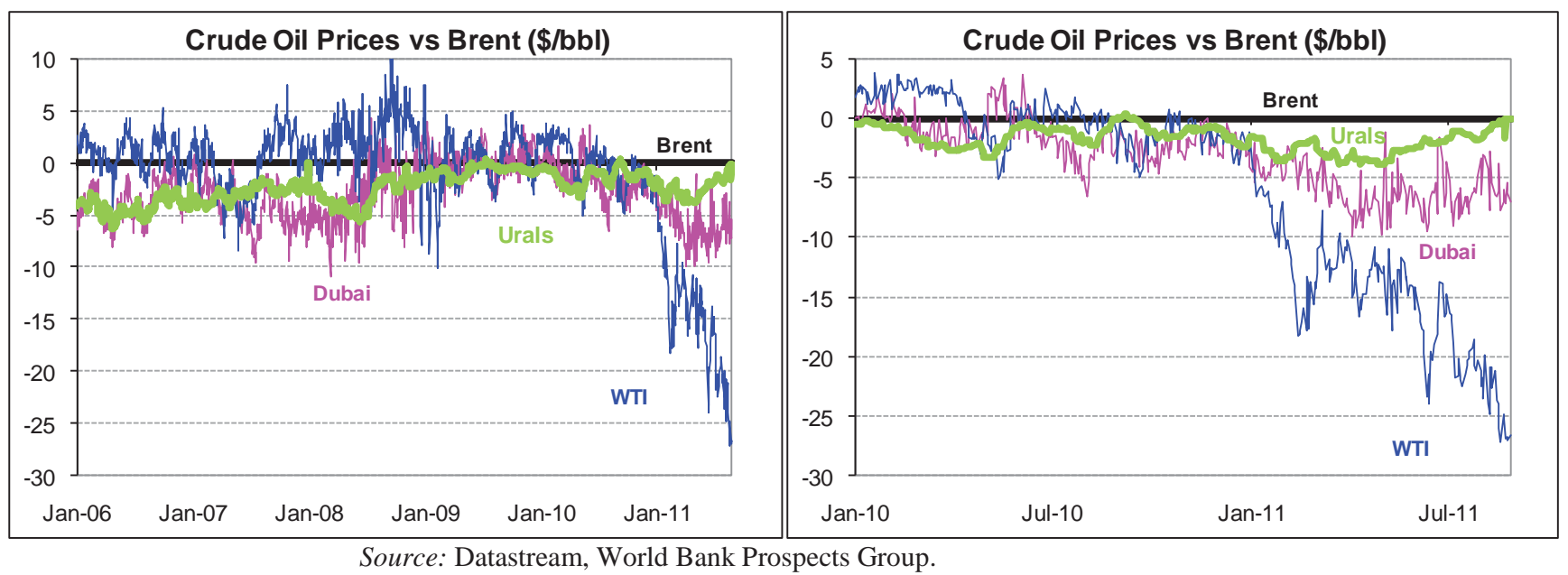

The differential between Brent and WTI is expected to narrow by 2015 because of the expected construction of new pipelines to the U.S. Gulf and Canadian Pacific coasts (figure 3.5). However, rising U.S. and Canadian crude production is expected to keep WTI from returning to premium status. The price of Urals is expected decline relative to Brent, because of return of the light/sweet crude output, and because incremental OPEC output is heavier crude. The price of Urals is projected to decline from US\$108.70/bbl in 2011 to US\$89.00/bbl in 2015.

Figure 3.5: Oil Price Differentials

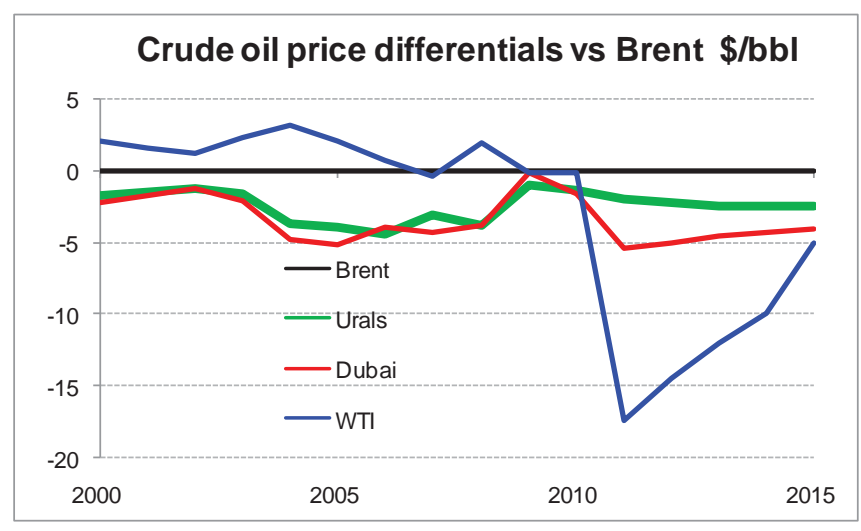

Source: World Bank Prospects Group.

\section{Oil Production in the Former Soviet Union}

Russia's oil production rose by $0.12 \mathrm{mb} / \mathrm{d}$ in the first seven months of 2011, with particularly strong growth of $0.2 \mathrm{mb} / \mathrm{d}$ over the February-May period (figure 3.6). Most of the growth was by Rosneft and the Private Companies. The IEA projects that the growth in Russia's oil production will slow to just 0.03 $\mathrm{mb} / \mathrm{d}$ in 2012. However, it has underestimated Russia and other non-OPEC producers in recent years, and output could well be higher again next year The IEA projects that Russia's oil output will decline slightly by 2015, but we assume that production will continue to rise moderately because of relatively high prices and expected policy changes that will sustain investment. 
Figure 3.6: Growth in Oil Supply in Former Soviet Union Countries

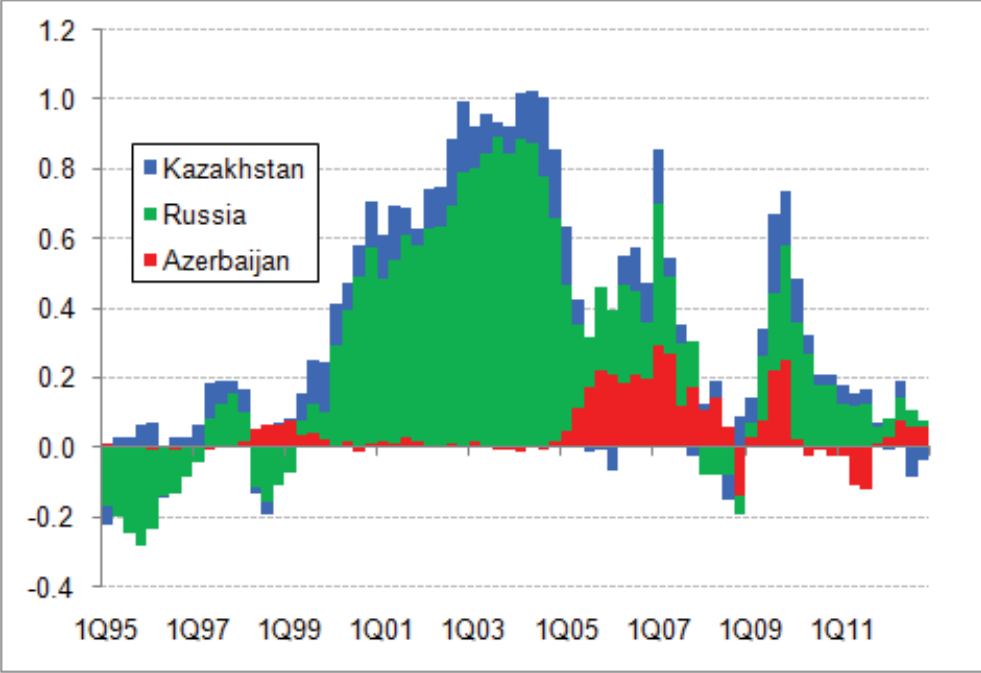

Source: International Energy Agency, Oil Market Report. 
Annex: Russian Federation: Main Economic Indicators, 2007-2011

\begin{tabular}{|c|c|c|c|c|c|c|c|c|c|c|c|c|c|c|c|c|c|c|c|}
\hline \multirow[b]{2}{*}{ Output Indicators } & \multirow{2}{*}{$\frac{2007}{\text { Jan-Dec }}$} & \multirow{2}{*}{$\frac{2008}{\text { Jan-Dec }}$} & \multirow{2}{*}{$\begin{array}{c}2009 \\
\text { Jan-Dec }\end{array}$} & \multicolumn{7}{|c|}{2010} & \multirow[b]{2}{*}{2010} & \multicolumn{7}{|c|}{2011} & \multirow[b]{2}{*}{ Aug } \\
\hline & & & & Jan & Feb & Mar & Apr & May & Jun & Jul & & Jan & Feb & Mar & Apr & May & June & July & \\
\hline GDP, \% change, y-o-y 1/ & 8.5 & 5.2 & -7.8 & - & - & 3.5 & - & - & 4.3 & - & 4.0 & - & - & 4.1 & - & - & 3.7 & - & \\
\hline Industrial production, $\%$ change, $\mathrm{y}-\mathrm{0}-\mathrm{y}$ & 6.8 & 0.6 & -9.3 & 10.2 & 8.4 & 9.8 & 10.4 & 12.6 & 9.7 & 5.9 & 8.2 & 6.7 & 5.8 & 5.3 & 4.5 & 4.1 & 5.7 & 5.2 & \\
\hline Manufacturing, $\%$ change, $\mathrm{y}-0-\mathrm{y}$ & 10.5 & 0.5 & -15.2 & 13.3 & 10.0 & 13.1 & 16.5 & 18.7 & 14.0 & 8.0 & 11.8 & 13.5 & 10.2 & 8.6 & 5.3 & 5.0 & 7.1 & 5.5 & \\
\hline Extraction of mineral resources, $\%$ change, y-o-y & 3.3 & 0.4 & -0.6 & 6.9 & 6.7 & 6.7 & 4.6 & 5.4 & 4.4 & 2.7 & 3.6 & 3.5 & 3.2 & 3.1 & 1.4 & 2.1 & 1.6 & 1.8 & \\
\hline Fixed capital investment, $\%$ change, $y-0-y$ & 21.1 & 9.8 & -16.2 & -8.3 & -7.5 & 0.4 & 1.7 & 5.6 & 8.3 & -0.5 & 6.0 & -4.7 & -0.4 & -0.3 & 2.2 & 7.4 & 4.9 & 7.9 & \\
\hline \multicolumn{20}{|l|}{ Fiscal and Monetary Indicators } \\
\hline Federal government balance, \% GDP 1/ & 5.4 & 4.1 & -5.9 & 2.4 & -8.6 & -3.2 & -3.4 & -3.3 & -1.9 & -2.2 & -4.1 & 4.2 & 0.7 & 1.1 & 0.9 & 2.0 & & 2.5 & \\
\hline Consolidated budget balance, $\%$ GDP $1 / 2$ & 6.1 & 4.8 & -6.2 & 13.4 & 7.4 & 2.5 & 2.3 & 1.7 & 1.3 & 1.2 & -3.6 & 13.9 & 6.2 & 7.1 & 5.6 & 7.3 & & & \\
\hline $\mathrm{M} 2, \%$ change, $\mathrm{p}-\mathrm{o}-\mathrm{p} 3 /$ & 51.3 & 27.2 & -3.5 & -2.3 & 1.5 & 2.8 & 2.7 & 2.3 & 2.2 & 0.8 & 30.6 & -3.5 & 1.2 & 1.5 & 1.2 & 0.7 & 2.7 & 0.5 & \\
\hline Inflation (CPI), \% change, p-o-p & 11.9 & 13.3 & 8.8 & 1.6 & 0.9 & 0.6 & 0.3 & 0.5 & 0.4 & 0.4 & 8.8 & 2.4 & 0.8 & 0.6 & 0.4 & 0.5 & 0.2 & 0.0 & -0.2 \\
\hline GDP deflator $1 /$ & 13.8 & 18.0 & 1.9 & - & - & 11.3 & - & - & 10.5 & - & 11.4 & - & - & 14.6 & - & - & & & \\
\hline Producer price index (PPI), \% change, p-o-p & 25.1 & -7.0 & 13.9 & -1.1 & 2.0 & 1.8 & 3.2 & 2.7 & -3.1 & 0.6 & 16.7 & 2.1 & 3.3 & 1.3 & 2.0 & 1.1 & -2.3 & -1.0 & \\
\hline Nominal exchange rate, average, Rb/USD & 25.6 & 24.8 & 31.7 & 29.9 & 30.2 & 29.6 & 29.2 & 30.4 & 31.2 & 30.7 & 30.4 & 30.1 & 29.3 & 28.4 & 28.1 & 27.9 & 28.0 & 27.9 & 28.8 \\
\hline Reserve Fund, bln USD e-o-p & & 137.1 & 60.5 & 59.9 & 58.9 & 52.9 & 40.6 & 39.3 & 39.3 & 40.6 & 25.4 & 26.0 & 26.1 & 26.3 & 27.1 & 26.6 & 26.6 & 26.6 & 26.8 \\
\hline National Wealth Fund, bln USD, e-o-p & & 88.0 & 91.6 & 90.6 & 89.6 & 89.6 & 88.8 & 85.8 & 85.5 & 88.2 & 88.4 & 90.2 & 90.9 & 91.8 & 94.3 & 92.5 & 92.6 & 92.7 & 92.6 \\
\hline \multicolumn{20}{|l|}{ Balance of Payment Indicators } \\
\hline$\frac{D}{\text { Trade Balance, billion S (monthly) }}$ & 130.9 & 179.7 & 112.1 & 16.3 & 15.0 & 15.2 & 14.3 & 12.5 & 12.5 & 10.4 & 151.4 & 14.7 & 17.7 & 16.9 & 19.1 & 16.6 & 17.4 & & \\
\hline Share of energy resources in export of goods, $\%$ & 61.5 & 65.9 & 62.8 & - & - & 67.1 & - & - & 63.3 & - & 63.5 & - & - & 68.2 & - & - & 65.0 & & \\
\hline Current Account, billions & 76.6 & 102.4 & 48.9 & 12.3 & 10.8 & 10.2 & 9.6 & 6.8 & 1.7 & 3.2 & 71.1 & - & - & 32.4 & - & - & 25.2 & & \\
\hline Export of goods, billion $\$$ & 354.4 & 471.6 & 304.0 & 27.7 & 30.6 & 34.0 & 33.5 & 31.8 & 32.1 & 31.4 & 400.1 & 31.0 & 39.4 & 43.8 & 46.1 & 44.6 & 44.9 & & \\
\hline Import of goods, billion S & 223.5 & 291.9 & 191.9 & 11.4 & 15.5 & 18.8 & 19.2 & 19.4 & 19.6 & 21.0 & 248.7 & 16.3 & 21.7 & 26.9 & 27.0 & 27.9 & 27.5 & & \\
\hline Gross FDI, mln USD 1/ & 27,797 & 27,027 & 15,906 & - & - & 2,623 & - & - & 5,423 & - & 13,810 & - & - & 3,890 & - & & 7,039 & & \\
\hline Average export price of Russia's oil, \$/bbl & 64.4 & 91.2 & 56.2 & 71.6 & 69.6 & 71.7 & 75.2 & 74.5 & 71.8 & 72.8 & 74.6 & 89.8 & 91.5 & 100.2 & 108.7 & 109.7 & 111.7 & & \\
\hline \multicolumn{20}{|l|}{ Financial Market Indicators } \\
\hline Average weighted lending rate for enterprises, $\% 4$ & 10.8 & 15.5 & 13.7 & 13.9 & 12.7 & 11.8 & 11.4 & 11.3 & 11.4 & 10.5 & 9.1 & 8.6 & 8.7 & 8.7 & 8.3 & 8.0 & 8.6 & 7.9 & \\
\hline CBR refinancing rate, $\%$, end-o-p & 10.0 & 13.0 & 8.8 & 8.8 & 8.5 & 8.3 & 8.0 & 7.8 & 7.8 & 7.8 & 7.8 & 7.8 & 8.0 & 8.0 & 8.0 & 8.3 & 8.3 & 8.3 & 8.3 \\
\hline Real average rate for Ruble loans, \% (deflated by PPI) & -3.4 & -6.8 & -0.1 & -2.3 & -0.4 & -0.1 & -1.2 & -3.3 & 2.0 & 2.3 & -6.5 & -9.9 & -10.9 & -10.5 & -9.7 & -8.6 & -8.8 & & \\
\hline Stock market index (RTS, ruble term, eop) & 2,291 & 632 & 1,445 & 1,474 & 1,411 & 1,572 & 1,573 & 1,385 & 1,339 & 1,480 & 1,770 & 1,910 & 1,970 & 2,044 & 2,027 & 1,889 & 1,907 & 1,965 & 1,702 \\
\hline \multicolumn{20}{|l|}{ Enterprises Finances } \\
\hline Share of loss-making companies 1 / & 23.4 & 25.2 & 30.1 & 38.6 & 37.8 & 38.8 & 37.1 & 35.5 & 34.4 & 33.4 & 27.8 & 37.1 & 36.9 & 38.6 & 36.6 & 35.0 & 34.7 & & \\
\hline Share of credits in capital investment 1 / & 15.5 & 17.6 & 20.1 & - & - & 15.9 & - & - & 15.8 & - & 14.3 & - & - & 11.2 & - & - & 13.4 & & \\
\hline Profitability (net profit/paid sales), \% $1 /$ & 36.8 & 21.5 & 28.7 & 59.4 & 43.3 & 38.2 & 37.0 & 34.7 & 32.2 & 33.3 & 32.7 & 62.7 & 48.0 & 42.5 & 40.7 & 40.9 & 37.5 & & \\
\hline \multicolumn{20}{|l|}{ Income, Porerty and Labor Market } \\
\hline Real disposable income, $(1999=100 \%)$ & 245.6 & 252.2 & 257.0 & 201.1 & 245.9 & 253.0 & 275.0 & 256.3 & 268.9 & 269.7 & 267.5 & 205.8 & 244.4 & 246.6 & 264.7 & 241.9 & 273.8 & 271.1 & \\
\hline Average dollar wage, US S & 532.0 & 696.9 & 588.3 & 622.3 & 635.0 & 701.3 & 695.0 & 665.0 & 698.6 & 706.4 & 697.8 & 696.6 & 714.6 & 797.5 & 818.9 & 811.5 & 859.6 & 863.3 & \\
\hline Unemployment $(\%$, ILO definition) & 6.1 & 7.8 & 8.2 & 9.2 & 8.6 & 8.6 & 8.2 & 7.3 & 6.8 & 7.0 & 7.2 & 7.8 & 7.6 & 7.1 & 7.2 & 6.4 & 6.1 & 6.5 & \\
\hline \multicolumn{20}{|l|}{ Source: Goskomstat, CBR, EEG, IMF, staff estimates. } \\
\hline 1/ Cumulative from the year beginning. & & & & & & & & & & & & & & & & & & & \\
\hline 2/ Starting 2006 incl. extrabudgetary funds. & & & & & & & & & & & & & & & & & & & \\
\hline 3/ Annual change is calculated for average annual $M$ & & & & & & & & & & & & & & & & & & & \\
\hline
\end{tabular}

